Article

\title{
Direct Exposure of Dry Enzymes to Atmospheric Pressure Non-Equilibrium Plasmas: The Case of Tyrosinase
}

\author{
Annamaria Lapenna ${ }^{1,2}$, Fiorenza Fanelli ${ }^{3, *(1)}$, Francesco Fracassi ${ }^{1,3}$, Vincenza Armenise ${ }^{1}(\mathbb{D}$, \\ Valeria Angarano ${ }^{1}$, Gerardo Palazzo ${ }^{1,2,3}$ (D) and Antonia Mallardi ${ }^{4, *}$ \\ 1 Department of Chemistry, University of Bari 'Aldo Moro', via Orabona 4, 70125 Bari, Italy; \\ annamaria.lapenna@uniba.it (A.L.); francesco.fracassi@uniba.it (F.F.); vincenza.armenise@uniba.it (V.A.); \\ Valeria.Angarano@kuleuven.be (V.A.); gerardo.palazzo@uniba.it (G.P.) \\ 2 Center for Colloid and Surface Science (CSGI), c/o Department of Chemistry, University of Bari 'Aldo Moro', \\ via Orabona 4, 70125 Bari, Italy \\ 3 National Research Council, Institute of Nanotechnology (CNR-NANOTEC), c/o Department of Chemistry, \\ University of Bari 'Aldo Moro', via Orabona 4, 70125 Bari, Italy \\ 4 National Research Council, Institute for Chemical-Physical Processes (CNR-IPCF), c/o Department of \\ Chemistry, University of Bari 'Aldo Moro', via Orabona 4, 70125 Bari, Italy \\ * Correspondence: fiorenza.fanelli@cnr.it (F.F.); a.mallardi@ba.ipcf.cnr.it (A.M.); Tel.: +39-080-5442227 (F.F.); \\ +39-080-5442226 (A.M.)
}

Received: 6 April 2020; Accepted: 6 May 2020; Published: 9 May 2020

\begin{abstract}
The direct interaction of atmospheric pressure non-equilibrium plasmas with tyrosinase (Tyr) was investigated under typical conditions used in surface processing. Specifically, Tyr dry deposits were exposed to dielectric barrier discharges (DBDs) fed with helium, helium/oxygen, and helium/ethylene mixtures, and effects on enzyme functionality were evaluated. First of all, results show that DBDs have a measurable impact on Tyr only when experiments were carried out using very low enzyme amounts. An appreciable decrease in Tyr activity was observed upon exposure to oxygen-containing DBD. Nevertheless, the combined use of X-ray photoelectron spectroscopy and white-light vertical scanning interferometry revealed that, in this reactive environment, Tyr deposits displayed remarkable etching resistance, reasonably conferred by plasma-induced changes in their surface chemical composition as well as by their coffee-ring structure. Ethylene-containing DBDs were used to coat tyrosinase with a hydrocarbon polymer film, in order to obtain its immobilization. In particular, it was found that Tyr activity can be fully retained by properly adjusting thin film deposition conditions. All these findings enlighten a high stability of dry enzymes in various plasma environments and open new opportunities for the use of atmospheric pressure non-equilibrium plasmas in enzyme immobilization strategies.
\end{abstract}

Keywords: atmospheric pressure plasma; dielectric barrier discharge; tyrosinase; enzyme immobilization; plasma chemistry; plasma etching; polymer coating; PECVD; XPS

\section{Introduction}

Enzymes are biocatalysts ubiquitous in plants, animals, and microorganisms, being able to accelerate many biochemical and chemical reactions. Their application has been therefore proposed in industrial, analytical, and biotechnological fields [1-7]. However, enzyme utilization is often hampered by the lack of long-term operational stability as well as by difficulties in enzyme recovery and reuse [1-7]. Enzyme immobilization on solid supports offers an efficient route to overcome the above limitations, as it facilitates the recovery of the biocatalyst over multiple reaction cycles [1-7]. 
Indeed, compared to their free form, immobilized enzymes generally exhibit improved stability and robustness to support applications in various domains [4-9]. Notwithstanding this, generalizable immobilization procedures are far from being assessed, because the widely different structural and functional characteristics of enzymes do not allow identifying a single procedure and solid support suitable for all enzymes and their diverse applications [5]. Moreover, each immobilization method has its own advantages and disadvantages [5-16]. Adsorption is simple, cheap, and effective, but very often reversible; covalent bonding effectively improves durability, but is expensive and easily worsens enzyme performance; encapsulation (or confinement) suffers from problems associated with mass-transfer limitations. Interestingly, recent studies have proposed the fruitful combination of two immobilization methods such as enzyme adsorption on a suitable support and subsequent overcoating with a protective thin film [17-19]. With this approach, the enzyme maintains sufficient conformational freedom while entrapped under the thin layer, which prevents enzyme leaching and allows the passage of substrates and products.

Over the last decades, low pressure non-equilibrium (cold) plasma processes have been exploited in a plethora of immobilization strategies [17,19-26]. They have been successfully used, for instance, (i) to properly modify the surface chemistry and morphology of various solid supports to enhance enzyme adsorption [19-21], (ii) to functionalize the support surface with specific chemical groups that can act as covalent binding sites for enzyme attachment [22-25], (iii) to immobilize enzyme by overcoating or entrapment with a plasma-deposited thin film [17,19,20,26].

The research in this field has received renewed impetus in recent years due to the development of atmospheric pressure (AP) plasma technology, which represents nowadays a new avenue for surface processing of materials with reduced costs and easy-to-handle apparatuses, even under open air conditions [27-35]. Novel strategies have been proposed for enzyme immobilization. Relevant examples include, for instance, the injection of the aerosol of an enzyme solution in the AP cold plasma to obtain either (i) the deposition of a biocomposite coating consisting of a plasma-polymerized organic matrix in which the enzyme remains entrapped [28,29], or (ii) the enzyme plasma polymerization, which leads to the deposition of a bioactive layer with no added matrix or encapsulant material [33]. It has been also demonstrated that, due to their remote operation, atmospheric pressure plasma jets offer a unique tool towards enzyme immobilization under soft reactive conditions [33]. Indeed, they can afford the desired surface modification with easier, faster, and more cost-effective plasma processes [27,32-34]. Moreover, considerable efforts have been devoted to investigate the direct interaction of AP non-equilibrium plasmas with various biomolecules (e.g., proteins and nucleic acids) both in the dry state and in aqueous solutions, focusing on many different biomedical, biotechnological, and pharmaceutical applications [28,35-45].

We recently proposed a two-step immobilization procedure in which the enzyme glucose oxidase (GOx) from Aspergillus niger is first deposited on a support, and subsequently coated with a polymer layer by using atmospheric pressure plasma-enhanced chemical vapor deposition (PECVD) [35]. A systematic investigation of effects of plasma exposure on GOx functionality was carried out by evaluating the influence of the enzyme amount as well as of various process parameters (e.g., plasma excitation conditions, feed gas composition, exposure time). We demonstrated that GOx activity can be preserved by proper selection of both the enzyme exposed amount and plasma processing conditions. We also envisaged that the proposed immobilization strategy could be applied also to other enzymes. However, each enzyme is expected to be sensitive in a peculiar way to plasma exposure during the immobilization procedure, which could produce changes and distortions in enzyme structure, and in turn, induce its partial or total inactivation [35]. To assess the versatility of our approach, the interaction of AP non-equilibrium plasmas with other enzymes needs therefore to be investigated.

Here, we focus our attention on mushroom tyrosinase (Tyr), i.e., a copper-containing enzyme, which in presence of oxygen catalyzes the $o$-hydroxylation of monophenols and the oxidation of $o$-diphenols into reactive $o$-quinones, which undergo spontaneous polymerization leading to dark compounds (e.g., melanine) [46-48]. In particular, Tyrosinase from Agaricus bisporus is a heterotetramer 
comprising two heavy $(\mathrm{H})$ and two light (L) chains, with a molecular mass of about $130 \mathrm{kDa}$ [47]. Its structural characteristics are very different from that of glucose oxidase from Aspergillus niger, which is a highly glycosylated homodimer, containing iron, with a molecular mass of about $160 \mathrm{kDa}$ [49].

Specifically, in this work, very tiny amounts of Tyr from Agaricus bisporus were deposited on a solid support by drop casting, and after drying, exposed to atmospheric pressure dielectric barrier discharges (DBDs). To explore different scenarios that may occur when DBDs interact with the enzyme, a range of chemical environments and processing conditions typically used in surface modification was investigated. Therefore, DBDs were fed with pure helium, helium/oxygen, and helium/ethylene mixtures, to reproduce the main plasma processes relevant to surface engineering, i.e., plasma treatment, plasma etching, and PECVD, respectively. In particular, ethylene-containing DBDs led to the deposition of a hydrocarbon polymer thin film onto dry Tyr $[35,50]$. After plasma exposure, the enzyme was dissolved in buffer solution and its activity was spectrophotometrically followed. X-ray photoelectron spectroscopy (XPS) and white light vertical scanning interferometry (WLVSI) were used to characterize Tyr dry deposits before and after plasma exposure. The results are discussed and compared with those previously obtained for GOx [35], to gain insights into processes that can take place when DBDs interacts with dry enzymes and to enlighten new opportunities for the use of AP non-equilibrium plasmas in enzyme surface engineering.

\section{Materials and Methods}

\subsection{Reagents}

Tyrosinase from mushroom ( $\geq 1000 \mathrm{unit} / \mathrm{mg}$ solid) and dopamine hydrochloride were purchased from Sigma-Aldrich (Milan, Italy). Di-sodium hydrogen phosphate and sodium di-hydrogen phosphate were bought from Fluka (Rodano, Italy). Compressed helium (99.9995\%) and oxygen (99.999\%) gas cylinders were purchased from Sol (Monza, Italy), while ethylene (99.95\%) was bought from Air Liquide Italia Service (Ostuni, Italy).

\subsection{DBD Reactor and Plasma Processes}

Plasma processes were carried out using an home-made atmospheric pressure plasma reactor with DBD electrode configuration, as described previously in full detail $[35,50]$. The plasma was generated by applying a sinusoidal high voltage $(\mathrm{HV})$ between two parallel plate electrodes $\left(50 \times 50 \mathrm{~mm}^{2}\right.$ electrode area, $4 \mathrm{~mm}$ gas gap), both covered with a dielectric alumina plate $[35,50]$. Experiments were carried out at the fixed excitation frequency (f) of $20 \mathrm{kHz}$ and applied voltages $\left(\mathrm{V}_{\mathrm{a}}\right)$ of 0.85 and $1.1 \mathrm{kV}$ rms (Table 1 ). The electrical characterization of the DBD was accomplished with a digital oscilloscope; the voltage applied to the electrodes was measured by means of a HV probe and the total current flowing through the circuit was determined indirectly by measuring the voltage drop across a $50 \Omega$ resistor connected in series with the ground electrode $[35,50,51]$. The average specific power dissipated by the discharge $\left(\mathrm{P}_{\mathrm{S}}\right)$ was calculated as the integral over one cycle of the product of the applied voltage and the current, divided by the period and the electrode area $[35,50]$.

Table 1. Plasma processing conditions investigated in the present work.

\begin{tabular}{|c|c|c|c|c|c|c|c|}
\hline $\begin{array}{c}\text { Feed } \\
\text { Mixture }\end{array}$ & $\begin{array}{c}\mathbf{f} \\
(\mathbf{k H z})\end{array}$ & $\begin{array}{c}V_{a} \\
\left(k V_{r m s}\right)\end{array}$ & $\begin{array}{c}P_{s} \\
\left(W \cdot \mathrm{cm}^{-2}\right)\end{array}$ & $\begin{array}{l}\Phi_{\mathrm{He}} \\
\text { (slm) }\end{array}$ & $\begin{array}{c}{\left[\mathrm{O}_{2}\right]} \\
(\%)\end{array}$ & $\begin{array}{c}{\left[\mathrm{C}_{2} \mathrm{H}_{4}\right]} \\
(\%)\end{array}$ & $\begin{array}{c}t \\
(\min )\end{array}$ \\
\hline $\mathrm{He}$ & 20 & 1.10 & $0.35 \pm 0.04$ & 8 & - & - & $10,30,60$ \\
\hline $\mathrm{He} / \mathrm{O}_{2}$ & 20 & 1.10 & $0.40 \pm 0.04$ & 8 & 1.0 & - & $10,30,60$ \\
\hline $\mathrm{He} / \mathrm{C}_{2} \mathrm{H}_{4}$ & 20 & 1.10 & $0.40 \pm 0.04$ & 8 & - & $0.3,0.5,1.0$ & 30 \\
\hline $\mathrm{He} / \mathrm{C}_{2} \mathrm{H}_{4}$ & 20 & 0.85 & $0.25 \pm 0.05$ & 8 & - & 0.3 & 30 \\
\hline $\mathrm{He}-\mathrm{C}_{2} \mathrm{H}_{4}$ & 20 & 0.85 & $0.25 \pm 0.05$ & 8 & - & $0.1,0.3,0.5$ & 10 \\
\hline
\end{tabular}


The DBD electrode system was located into an airtight Plexiglas chamber, kept at constant pressure $\left(10^{5} \mathrm{~Pa}\right)$. Before each experiment, the chamber was purged with $6 \mathrm{slm}$ (standard liters per minute) of He for $20 \mathrm{~min}$ to reduce air contaminations. During plasma processes, the samples were placed in the middle of the discharge region, onto the alumina plate covering the lower electrode. DBDs fed with $\mathrm{He}, \mathrm{He} / \mathrm{O}_{2}$, and $\mathrm{He} / \mathrm{C}_{2} \mathrm{H}_{4}$ mixtures were utilized. He flow rate $\left(\Phi_{\mathrm{He}}\right)$ was kept fixed at $8 \mathrm{slm}$, $\mathrm{O}_{2}$ concentration $\left(\left[\mathrm{O}_{2}\right]\right)$ in the $\mathrm{He} / \mathrm{O}_{2}$ mixture was equal to $1 \%$ (hereafter referred to as $\mathrm{He} / 1 \% \mathrm{O}_{2}$ mixture), ethylene concentration $\left(\left[\mathrm{C}_{2} \mathrm{H}_{4}\right]\right)$ in $\mathrm{He}_{-} \mathrm{C}_{2} \mathrm{H}_{4}$ mixtures was varied in the range $0.1-1 \%$. Process duration ( $\mathrm{t}$ ), also referred to as plasma exposure time, was varied between 10 and $60 \mathrm{~min}$. Table 1 summarizes plasma processing conditions investigated in this study.

\subsection{Sample Preparation, Manipulation and Enzyme Functionality Assay}

Figure 1 summarizes the main steps of the experimental procedure utilized in this work. Five-microliter drops of enzyme solution in deionized water were deposited on round borosilicate glass slides (Figure 1a; slide diameter and thickness of 12 and $0.15 \mathrm{~mm}$, respectively) and dried under reduced pressure for $30 \mathrm{~min}$, leading to the formation of a ring-shaped Tyr deposit (Figure 1b). The amount of dry tyrosinase used in the experiments is expressed as micrograms of enzyme present in the $5-\mu \mathrm{L}$ drop. A set of slides was prepared and retained to be used as control samples, while a second set was placed in the DBD reactor, to be subjected to the selected plasma process (Figure 1c). It is worth specifying that sample placement in the discharge region does not appreciably alter both gas flow dynamics and plasma behavior. This is mainly due to the fact that the support selected for this work (i.e., the glass slide) is made of a dielectric material and is both very thin $(0.15 \mathrm{~mm})$ and considerably thinner than the gas gap (4 mm) [52].

After that, each slide was immersed in $1 \mathrm{~mL}$ of buffer solution (i.e., sodium phosphate buffer) to obtain enzyme solubilization in a few seconds, under mild stirring (Figure 1d). The rapid and complete resolubilization of the enzyme in aqueous buffer indicates that interactions with glass (likely van der Walls and possibly H-bonds) are weaker than the interaction of Tyr with water. A polypropylene pipette tip was used to scratch the hydrocarbon thin film deposited on dry Tyr by helium-ethylene fed DBDs [35], allowing the release of the entrapped enzyme in the buffer solution through the lacerations made with the tip. Also, in this case the solubilization of the dried enzyme occurs in a few seconds. Control experiments showed that, after solubilization, the recovered activity of $10 \mu \mathrm{g}$ of Tyr dried and exposed to ethylene-containing DBDs equals that recorded for the same amount of free enzyme in solution, accounting for a total enzyme recovery after scratching.

(a)

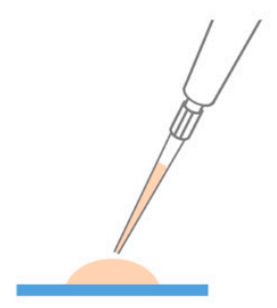

(b)

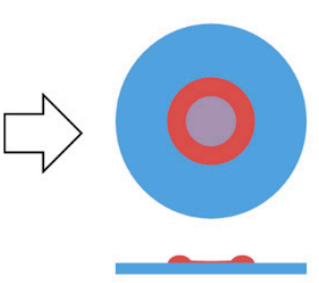

(c)

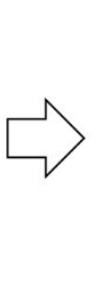

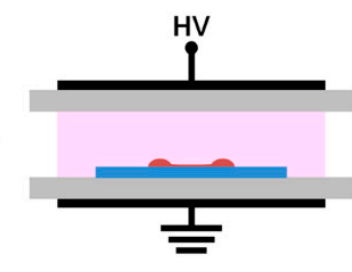

(d)

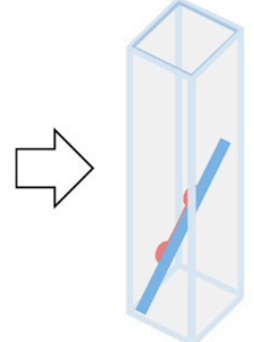

Figure 1. Schematic diagram summarizing the main steps of the experimental procedure used in this work: (a) deposition of a 5- $\mu \mathrm{L}$ drop of Tyr solution on a glass slide; (b) drying of the Tyr solution under reduced pressure; (c) exposure of the dry Tyr deposit to the atmospheric pressure dielectric barrier discharge (DBD); (d) Tyr solubilization in buffer solution for spectrophotometric assay.

After solubilization, the enzyme activity was evaluated by a spectrophotometric assay carried out with a V-530 spectrophotometer (Jasco, Easton, PA, USA). Dopamine was used as substrate (S) and the increase in absorbance at $475 \mathrm{~nm}$, due to dopaminechrome formation, was measured [48]. The assay 
was performed in $20 \mathrm{mM}$ sodium phosphate buffer at $\mathrm{pH} 7.0$, for a total volume of $1 \mathrm{~mL}$. In a typical activity assay, the reaction started upon addition of $6 \mathrm{mM}$ of dopamine (dopamine concentration $>>$ Michaelis constant), then the absorbance increase was monitored. Reaction rates are expressed in absorbance $\min ^{-1}$. The residual activity was determined as the percentage ratio between the reaction rate measured for the enzyme exposed to the plasma and the reaction rate measured for the same amount of enzyme dried out on a glass slide but not exposed to plasma (i.e., the control). Importantly, it was duly verified that (i) the drying procedure does not alter Tyr activity, which for the control sample is fully recovered after solubilization; (ii) no changes occur in Tyr activity when samples are placed in the DBD reactor and exposed to the He purging flow as well as to the various feed mixtures without plasma ignition. It should be also noted that the bioactivity of the dried enzyme deposit does not seem to be affected by the temperature to which it is exposed in the reactor during the plasma process (in our conditions the electrode temperature does not exceed $45^{\circ} \mathrm{C}$ ). Control experiments showed that, after solubilization, the recovered activity of $10 \mu \mathrm{g}$ of Tyr dried and exposed to different plasmas for 60 min equals that recorded for the same amount of free enzyme in solution. Therefore, all changes in enzyme functionality observed in this study can be traced back to plasma exposure.

After selected plasma processes, the Michaelis-Menten plot of initial rate $\left(\mathrm{V}_{0}\right)$ versus substrate concentration ([S]) was generated, by varying dopamine concentration between 0.1 and $6 \mathrm{mM}$. The Michaelis-Menten constant $\left(\mathrm{K}_{\mathrm{m}}\right)$ and the maximum velocity $\left(\mathrm{V}_{\max }\right)$ were determined. The error estimation of the parameters obtained by the fits was performed by Monte Carlo simulation using a suitable worksheet script in the OriginPro 8 SR0 v8.0724 (B724) package (OriginLab Corporation). The overall procedure is described below. The parameters obtained by fitting the set of experimental data to the Michaelis-Menten (M-M) function (Equation (1))

$$
\mathrm{V}_{0}=\frac{\mathrm{V}_{\max }[\mathrm{S}]}{\mathrm{K}_{\mathrm{m}}+[\mathrm{S}]}
$$

were used to create "perfect" (noise free) data sets. Random noise, corresponding to the standard deviation obtained by the best-fit of the experimental data, was added to the perfect data set. The data were then fitted by a least-squares routine to Equation (1). This process was repeated 1000 times, taking care to add a different set of noise to the perfect data before each cycle. Best-fit parameters were analyzed for both the mean and standard deviation.

\subsection{Topographical and Surface Chemical Characterization of Enzyme Deposits}

White light vertical scanning interferometry (WLVSI) enabled the three-dimensional imaging of the dry enzyme deposits as well as the determination of their thickness before and after plasma exposure. Analyses were carried out using a Contour GT-K0X 3D optical microscope (Bruker, Tucson, AZ, USA) equipped with a 50x Mirau-type interferometric objective and a $0.55 x$ camera zoom $\left(0.23 \times 0.17 \mathrm{~mm}^{2}\right.$ field of view). In particular, for each sample, the thickness of the Tyr deposit was measured at four fixed locations of the ring-shaped structure (6 measurements per location). The residual thickness was determined as the percentage ratio between the mean thickness after and before plasma exposure. The thickness of the hydrocarbon polymer films deposited by $\mathrm{He}-\mathrm{C}_{2} \mathrm{H}_{4}$ fed DBDs onto glass slides was determined using an Alpha-Step ${ }^{\circledR}$ D-120stylus profiler (KLA-Tencor, Milpitas, CA, USA) as previously reported [35]. The deposition rate (DR) was estimated dividing the film thickness by the deposition time [50].

X-ray photoelectron spectroscopy (XPS) analyses were performed with a PHI VersaProbe II spectrometer (ULVAC-PHI, Inc., Kanagawa, Japan) using a monochromatic Al K $\alpha$ X-ray source $(1486.6 \mathrm{eV}$ ) operated at a spot size of $100 \mu \mathrm{m}$ (power of $24.5 \mathrm{~W})$. Survey $(0-1400 \mathrm{eV}$ ) and high resolution (C 1s, O 1s, N 1s, S 2p, K 2p, Na 1s, P 2p) spectra were recorded in fixed analyzer transmission mode at pass energy of 117.4 and $46.95 \mathrm{eV}$, respectively. The spectrometer was equipped with an $\mathrm{X}$-ray beam induced secondary electron imaging (SXI) system, which enabled the confident location of the analyzed spots on enzyme ring-shaped deposits. All spectra were acquired at a take-off angle of $45^{\circ}$ with respect to the sample normal. Dual-beam charge neutralization was used during analysis to compensate 
charging effects. Special care was devoted to verify that no changes were induced in the samples by X-ray beam exposure. Data processing was performed using MultiPak software (Version 9.5.0.8, 30-10-2013, Ulvac-PHI, Inc., Kanagawa, Japan). The calibration of the binding energy (BE) scale was performed by fixing the position of the hydrocarbon component of the high-resolution $C 1$ s spectrum at $285.0 \pm 0.2 \mathrm{eV}[35,50,51]$. The high-resolution $\mathrm{C} 1 \mathrm{~s}, \mathrm{O} 1 \mathrm{~s}$, and $\mathrm{N} 1 \mathrm{~s}$ spectra were curve fitted with mixed Gaussian-Lorentzian peaks after Shirley background subtraction, as described previously in full detail [35]. Analyses were repeated on two samples exposed to DBD in two different experiments (three analyzed points per sample). A maximum relative standard deviation of $10 \%$ was estimated on XPS surface atomic concentrations and on the peak area percentages of the curve-fitting components.

It was preliminarily verified by XPS and WLVSI that no changes occur in the surface chemical composition and morphology of the enzyme deposits after exposure to the He purging flow and to the various feed mixtures in the DBD reactor, without plasma ignition.

\section{Results and Discussion}

This study focuses on the investigation of the direct exposure of dry tyrosinase from Agaricus bisporus to atmospheric pressure non-equilibrium plasmas, generated in DBD configuration. The aim is to provide a clear and comprehensive picture of DBD effects on Tyr functionality over a range of chemical environments and experimental conditions typically used in surface processing of materials (Table 1). In particular, to explore different scenarios that may occur when an AP plasma interacts with the enzyme, Tyr dry deposits were exposed to DBDs fed with:

1. Pure He. Helium is used in large amount, as main gas, in many AP plasma processes $[27,35$, 36,39,51-57]. DBDs fed by a pure noble gas (e.g., helium or argon) are often exploited for the plasma treatment of organic materials, i.e., to induce moderate changes in the surface roughness as well as in the chemical composition of the outermost layers of these materials [27,55-57]. Electrical excitation conditions used in this work (Table 1) fall within the operational window of a homogeneous DBD in He (i.e., DBD in glow regime) [27,52-54]. Figure S1a reports voltage and current signals registered under the selected conditions; as reported in the literature on homogeneous DBDs, the current signal is characterized by only one peak per half-cycle of the applied voltage and all positive (and negative) peaks exhibit almost the same shape, amplitude, and position in the cycle [54].

2. $\mathrm{He} / 1 \% \mathrm{O}_{2}$ mixture. Reactive oxygen species (ROSs) are effectively produced in AP non-equilibrium plasmas even at low $\mathrm{O}_{2}$ feed concentrations. They induce extensive surface chemical modifications as well as considerable etching of carbon-based materials with formation of volatile products $[27,55]$. Importantly, ROSs are widely known to cause biomolecule damage [36,38,40,43]. The investigation of this feed mixture allows also evaluating possible detrimental effects induced by the presence of a severe $\mathrm{O}_{2}$ contamination in the plasma. In this regard, it is worth mentioning that when plasma processes are carried out at atmospheric pressure in open-air conditions, $\mathrm{O}_{2}$ contamination inevitably occurs due to air entrainment into the plasma region [27,36]. The $\mathrm{O}_{2}$ concentration and electrical conditions used in this work (Table 1) are optimized to obtain plasma etching of polymers with uniform etching rate over the entire sample (e.g., $\sim 55 \mathrm{~nm} \cdot \mathrm{min}^{-1}$ in case of a polyethylene-like coating deposited using a He- $\mathrm{C}_{2} \mathrm{H}_{4}$ fed DBDs). Under the selected conditions, the DBD operates in filamentary regime [27,52-54], without any surface damage due to discharge localization and filamentation. Figure S1b shows that, due to microdischarges formation, the current signal is formed by several peaks per half-cycle of the applied voltage, which are not characterized by the same amplitude and position in different cycles [54].

3. $\mathrm{He} / \mathrm{C}_{2} \mathrm{H}_{4}$ mixtures. Atmospheric pressure plasma polymerization of ethylene leads to the deposition of a hydrocarbon polymer film (also referred to as polyethylene-like film) $[50,51,58]$ on the dry enzyme, to enable its immobilization. The investigation of $\mathrm{He} / \mathrm{C}_{2} \mathrm{H}_{4}$ fed DBDs allows, therefore, evaluating whether direct plasma interaction with Tyr during the PECVD process has a negative effect on its activity. The experimental conditions used in this work (Table 1) allow depositing 
a uniform and smooth polymer layer over the entire sample. As far as the coatings are concerned, by changing the ethylene concentration and the applied voltage, it is possible to vary their deposition rate from $\sim 20$ to $\sim 40 \mathrm{~nm} \cdot \mathrm{min}^{-1}$, without significant changes in their chemical composition and morphology [35]. With regard to the discharge regime, it is worth mentioning that at the excitation frequency of $20 \mathrm{kHz}$ : (i) the DBD operates in homogeneous regime when $\left[\mathrm{C}_{2} \mathrm{H}_{4}\right]$ and $\mathrm{V}_{\mathrm{a}}$ are lower or equal to $0.5 \%$ and $1.1 \mathrm{kV}_{\mathrm{rms}}$, respectively (voltage and current signals in Figure $\mathrm{S} 2 \mathrm{a}, \mathrm{b}$ ); (ii) the DBD operates in filamentary regime when $\left[\mathrm{C}_{2} \mathrm{H}_{4}\right]$ and $\mathrm{V}_{\mathrm{a}}$ are equal to $1 \%$ and $1.1 \mathrm{kV}_{\mathrm{rms}}$, respectively. Under these latter conditions, even if the current signal is characterized by only one peak per half-cycle of the applied voltage, all positive (and negative) peaks do not have the same amplitude (Figure S2c); moreover, discharge filamentation can be clearly perceived by the naked eye.

Results obtained under experimental conditions reported in Table 1 will be described and discussed in the following subsections. First, DBDs fed with pure $\mathrm{He}$ and $\mathrm{He} / 1 \% \mathrm{O}_{2}$ mixture will be examined (Section 3.1); effects on Tyrosinase functionality as well as on the thickness and surface chemical composition of the dry enzyme deposits will be presented. Then, attention will shift to the impact of PECVD from ethylene-containing DBDs on Tyr activity (Section 3.2). Finally, results will be compared with data previously obtained for glucose oxidase [35], to reveal similarities and differences among the two enzymes (Section 3.3).

\subsection{Exposure of Tyr to DBDs Fed with Pure He and $\mathrm{He} / 1 \% \mathrm{O}_{2}$ Mixture}

Plasma exposure seems to affect Tyr functionality only when very tiny amounts of enzyme are used in the experiments (i.e., 2 or $5 \mu \mathrm{g}$ ). In fact, when the amount of dry Tyr is equal to or greater than $10 \mu \mathrm{g}$, no activity reduction is observed even after long exposure (i.e., $\mathrm{t}>30 \mathrm{~min}$ ) to DBDs fed with pure $\mathrm{He}$ and $\mathrm{He} / 1 \% \mathrm{O}_{2}$ mixture. Results obtained for a plasma process duration of $30 \mathrm{~min}$ (Figure 2) can be summarized as follows: (i) the $\mathrm{He} / 1 \% \mathrm{O}_{2}$ fed DBD has no effect on Tyr activity when the exposed amount is $10 \mu \mathrm{g}$, while leads to similar values of residual activity in case of 2 and $5 \mu \mathrm{g}$ of Tyr $(70 \pm 5 \%$ and $67 \pm 2 \%$, respectively); (ii) exposure of both 2 and $5 \mu$ g of Tyr to the pure He DBD leads to a residual activity of about $85 \%$, greater than that observed in case of the $\mathrm{O}_{2}$-containing plasma, revealing that the He DBD has a lower impact on the enzyme activity than the $\mathrm{He} / 1 \% \mathrm{O}_{2}$ fed DBD.

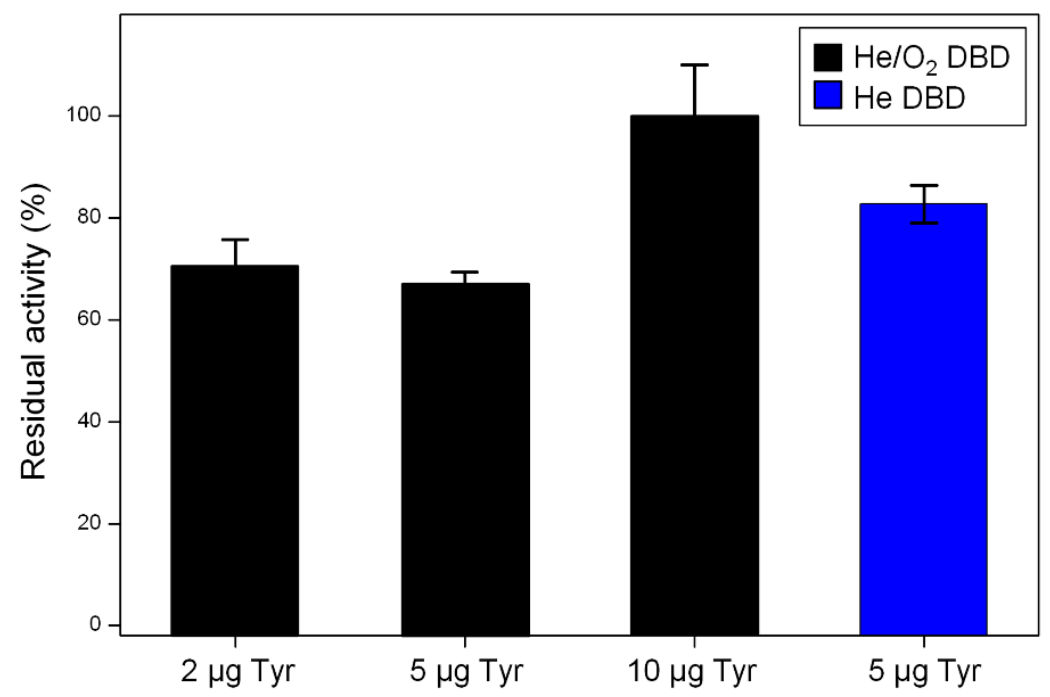

Figure 2. Tyrosinase residual activity after $30 \mathrm{~min}$ exposure to DBDs fed with $\mathrm{He} / 1 \% \mathrm{O}_{2}$ mixture (Tyr amount $=2,5,10 \mu \mathrm{g}$ ) and pure He (Tyr amount $=5 \mu \mathrm{g})$.

Figure 3a shows that the activity of $5 \mu \mathrm{g}$ of tyrosinase is reduced with increasing the exposure time to the $\mathrm{He} / 1 \% \mathrm{O}_{2}$ fed DBD. In particular, Tyr residual activity decreases to $\sim 85 \%$ upon $10 \mathrm{~min}$ 
exposure, drops to $\sim 65 \%$ when exposure time is increased to $30 \mathrm{~min}$, while remains constant for longer process duration. Very similar results are obtained as a function of the exposure time further decreasing the enzyme amount to $2 \mu \mathrm{g}$ (Figure S3). Moreover, when the plasma treatment is carried out using a pure He DBD, a residual activity of $\sim 85 \%$ is obtained, regardless of the process duration (Figure S3). Therefore, Tyr seems to display remarkable resistance upon plasma exposure, i.e., considerable activity retention is observed also when very low enzyme amounts are used, with very weak dependence on the exposed amount.

(a)

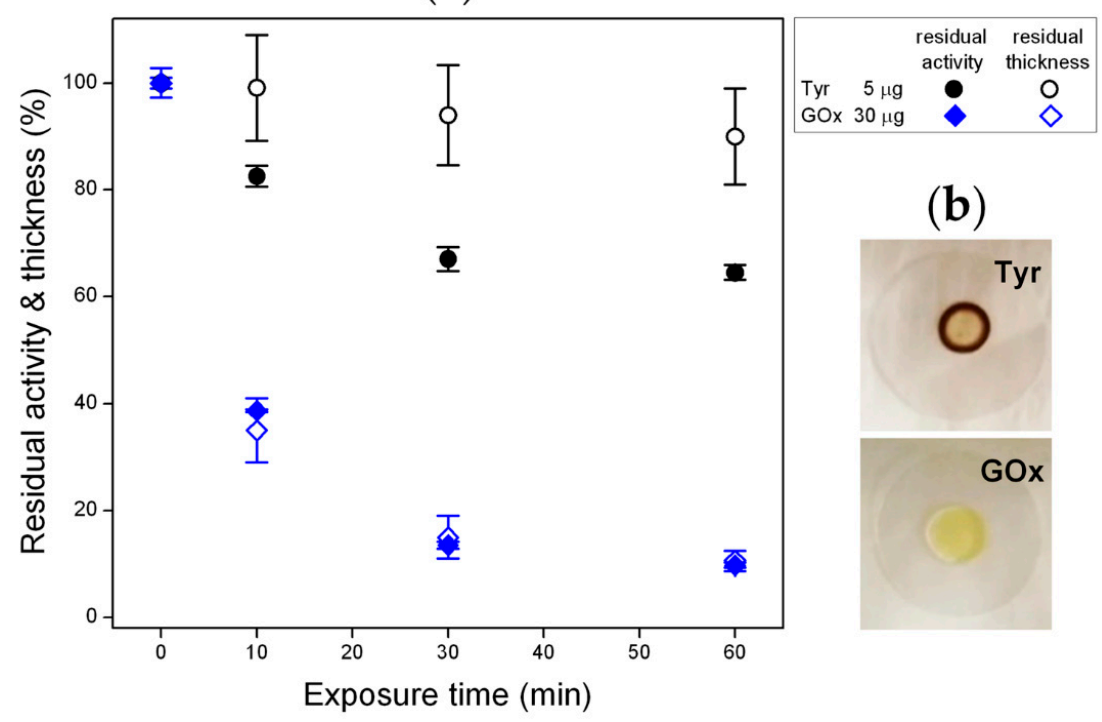

Figure 3. (a) Residual activity (closed symbols) and residual thickness (open symbols) of tyrosinase $(5 \mu \mathrm{g})$ and glucose oxidase $(30 \mu \mathrm{g})$ exposed to DBDs fed with $\mathrm{He} / 1 \% \mathrm{O}_{2}$ mixture for different times $\left(\mathrm{f}=20 \mathrm{kHz}, \mathrm{V}_{\mathrm{a}}=1.1 \mathrm{kV}_{\mathrm{rms}}\right.$ ). Glucose oxidase data are taken from Ref. [35]. (b) Representative pictures of Tyr and GOx deposits onto glass slides after drying (large amounts of enzyme were utilized to make the deposit morphology more visible in the pictures).

Upon drying, due to the so-called coffee-ring effect, the droplet of Tyr solution deposited on the glass slide leaves a ring-shaped solid structure with a diameter of $3.4 \pm 0.4 \mathrm{~mm}$ and a horizontal width of $\sim 0.15 \mathrm{~mm}$ (Figure 3b) $[40,43]$. As a consequence, the major fraction of the enzyme is confined in a thick annular deposit of area $1.53 \mathrm{~mm}^{2}$ with an effective protein surface density (total protein amount divided by the area occupied by the coffee-ring) of $3.27 \mu \mathrm{g} \cdot \mathrm{mm}^{2}$. The topography of the Tyr deposits was investigated by white light vertical scanning interferometry before and after exposure to the $\mathrm{He} / 1 \%$ $\mathrm{O}_{2}$ fed DBD. A representative bidimensional (2D) WLVSI image of a 5- $\mu$ g pristine deposit is reported in Figure 4a. Inhomogeneities and cracks are clearly visible. The height of the deposit measured on top of the coffee-ring structure is $6.5 \pm 1.0 \mu \mathrm{m}$ before plasma exposure.

The cross-section thickness profile of Figure $4 \mathrm{c}$ can be roughly described by a triangular shape. Taking into account that the coffee-ring thickness $(t)$ and horizontal width $(w)$ are much smaller than the radius $(\mathrm{R})$, we can describe the deposit volume, that is given by the protein mass divided by its density $\left(\sim 1.3 \mathrm{~g} \cdot \mathrm{mL}^{-1}[59]\right)$, as the volume $(\mathrm{V})$ of a triangular prism with length equal to the coffee-ring perimeter, $\mathrm{V}=\frac{1}{2} \mathrm{t} \cdot \mathrm{w} \cdot 2 \pi \mathrm{R}$. The goodness of such a description can be checked by evaluating the triangular prism height from the macroscopic parameters: protein mass $=5 \mu \mathrm{g}$, coffee-ring radius $\mathrm{R}=1.7 \mathrm{~mm}$ and width $\mathrm{w}=0.15 \mathrm{~mm}$. The calculation gives $5 \mu \mathrm{m}$ that is within $\sim 25 \%$ of the experimental value $6.5 \mu \mathrm{m}$ (i.e., the maximum thickness of the deposit determined by WLVSI). Within such an approximation, the surface area exposed to the plasma (A) can be evaluated as the area of the two oblique faces, $A=4 \pi R \sqrt{\left(\frac{w}{2}\right)^{2}+t^{2}}$, and it is possible to estimate the ratio between the exposed surface area and the overall volume (A/V) that in the case of a $5 \mu \mathrm{g}$ Tyr deposit is $0.43 \mu \mathrm{m}^{-1}$. The two-dimensional 
width and radius of the coffee-ring do not seem to vary appreciably with the deposited Tyr amount (as evaluated by the naked eye), so that the thickness of the deposit should depend mainly on the amount of protein. Within the above described approximation, $10 \mu \mathrm{g}$ and $2 \mu \mathrm{g}$ Tyr deposits have a maximum thickness of $8.4 \mu \mathrm{m}$ and $1.7 \mu \mathrm{m}$, respectively. The corresponding A/V ratios are $0.26 \mu \mathrm{m}^{-1}$ (for $10 \mu \mathrm{g}$ ) and $1.30 \mu \mathrm{m}^{-1}$ (for $2 \mu \mathrm{g}$ ). Although very crude, these calculations suggest that appreciable enzyme inactivation takes place only for high enough A/V ratios. Since the A/V ratio is proportional to fraction of protein on the surface, such evidence points towards surface reactions as the main source of enzyme damage with a negligible role of others factors such as increase in temperature and exposure to UV light that take place during the plasma process, but involve the whole protein volume.
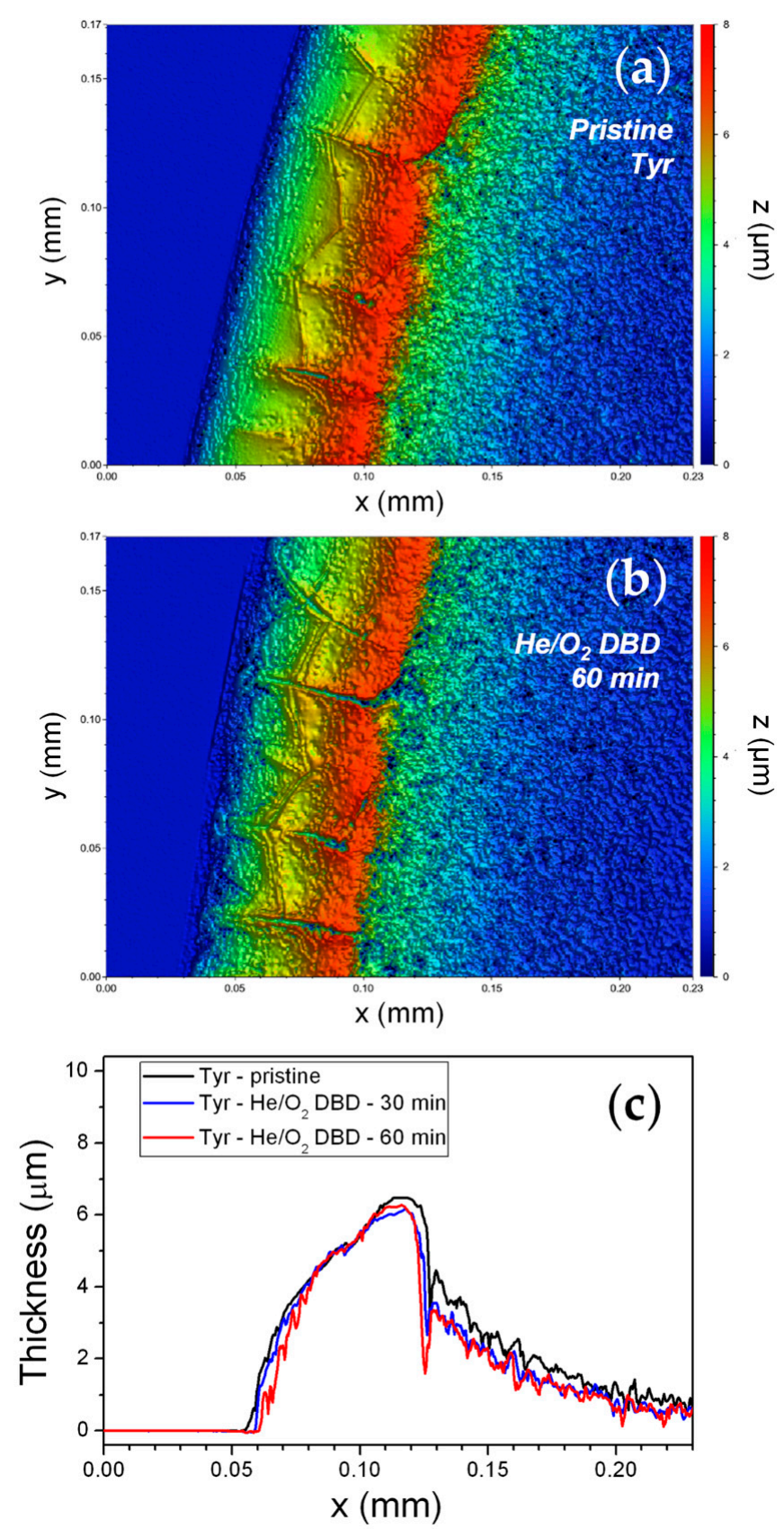

Figure 4. 2D white light vertical scanning interferometry (WLVSI) images of a $5 \mu \mathrm{g}$ Tyr deposit (a) before and (b) after exposure to a $\mathrm{He} / 1 \% \mathrm{O}_{2}$ fed DBD for $60 \mathrm{~min}\left(\mathrm{f}=20 \mathrm{kHz}, \mathrm{V}_{\mathrm{a}}=1.1 \mathrm{kV} \mathrm{rms}_{\text {s }}\right.$ ). (c) Cross-section thickness profiles of the Tyr deposit before and after exposure to the $\mathrm{He} / 1 \% \mathrm{O}_{2}$ fed DBD for 30 and $60 \mathrm{~min}$. 
Figure $4 \mathrm{~b}$ reports the WLVSI image acquired at the same sample position after 60 min exposure to the $\mathrm{He} / 1 \% \mathrm{O}_{2}$ fed plasma. A slight increase in the depth and width of cracks can be appreciated, along with a thickness decrease which seems to be more evident at the outer and inner rims of the deposit than at the deposit top. The filamentary character of the $\mathrm{O}_{2}$-contaning DBD seems not to cause localized damage of the Tyr deposit due to microdischarge formation. Cross-section thickness profiles obtained from WLVSI images (Figure 4c) show that, overall, deposit thickness weakly decreases with process duration. In particular, in case of a $5 \mu \mathrm{g}$ Tyr deposit, a few hundred nm decrease of the average thickness is observed after $60 \mathrm{~min}$, i.e., the average thickness reduction is about $\sim 10 \%$. Interestingly, the thickness of a polyethylene-like coating deposited in a He- $\mathrm{C}_{2} \mathrm{H}_{4}$ DBD decreases by $3.3 \pm 0.2 \mu \mathrm{m}$ upon exposure to the oxygen-containing DBD, under identical experimental conditions. This evidence suggests that moderate Tyr etching occurs upon $\mathrm{O}_{2}$-containing plasma exposure. On the other hand, the pure He DBD does not cause any morphological and thickness change in Tyr deposits.

Figure 3a reveals that, although similar trends are found for Tyr residual activity and deposit residual thickness as a function of the exposure time to the $\mathrm{He} / 1 \% \mathrm{O}_{2}$ fed DBD (5 $\mu \mathrm{g}$ Tyr), the residual thickness values are always greater than those of residual activity. For instance, after 60 min, residual thickness slightly decreases to $\sim 90 \%$, while residual activity drops to $\sim 65 \%$. It can be therefore inferred that Tyr removal via plasma etching only partially accounts for the activity reduction, and that a certain fraction of residual enzyme undergoes structural modifications upon plasma exposure, which could be responsible for inactivation and/or reduced enzyme affinity towards the substrate.

To clarify this point, the enzyme kinetic behavior was studied, determining the maximum reaction rate $\left(\mathrm{V}_{\text {max }}\right)$ and the Michaelis-Menten constant $\left(\mathrm{K}_{\mathrm{m}}\right)$ values of both the control (i.e., dried enzyme not exposed to the plasma) and the dried enzyme exposed to $\mathrm{He} / 1 \% \mathrm{O}_{2}$ fed plasma for 30 min. Treatment in pure helium DBD was not considered since it scarcely affects Tyr activity.

Considering an enzyme whose initial rate $\mathrm{V}_{0}$ obeys the Michaelis-Menten equation (Equation (1)), where [S] denotes the initial substrate (dopamine) concentration, we have that for large [S] values, $\mathrm{V}_{0} \sim \mathrm{V}_{\max } \propto[\mathrm{E}]$ and any process that reduces the concentration of the functional enzyme [E] decreases the experimental reaction rate. On the other hand, plasma processes could also impact the affinity (of the still functional enzyme) for the substrate, leading to different values of the M-M constant.

Representative M-M plots of the control and the plasma-treated enzyme are shown in Figure 5a. In both cases $\mathrm{V}_{0}$ vs. [S] plots are well accounted for by the $\mathrm{M}-\mathrm{M}$ equation (Equation (1)). The best-fit values are $\mathrm{V}_{\max }=0.39 \pm 0.01 \mathrm{Abs} \cdot \mathrm{min}^{-1}$ and $\mathrm{K}_{\mathrm{m}}=0.32 \pm 0.04 \mathrm{mM}$ for the control and $\mathrm{V}_{\max }=0.30 \pm 0.01$ Abs. $\min ^{-1}$ and $\mathrm{K}_{\mathrm{m}}=0.29 \pm 0.04 \mathrm{mM}$ for the enzyme exposed to the oxygen-containing DBD. With respect to the control, a more evident decrease $(23 \%)$ in $V_{\max }$ is observed after exposure to the $\mathrm{He} / 1 \% \mathrm{O}_{2}$ fed DBD (i.e., decrease in the plateau at high [S]), while $\mathrm{K}_{\mathrm{m}}$ reduction is smaller $(<10 \%)$. The Monte-Carlo analysis of the best-fit of the $\mathrm{M}-\mathrm{M}$ equation indicates that the $23 \%$ decrease in $\mathrm{V}_{\max }$ is statistically relevant (Figure 5b), while the small decrease in $K_{m}$ (Figure $5 c$ ) is likely due to the statistical positive correlation between $\mathrm{V}_{\max }$ and $\mathrm{K}_{\mathrm{m}}$ shown in the inset of Figure $5 \mathrm{a}$. 

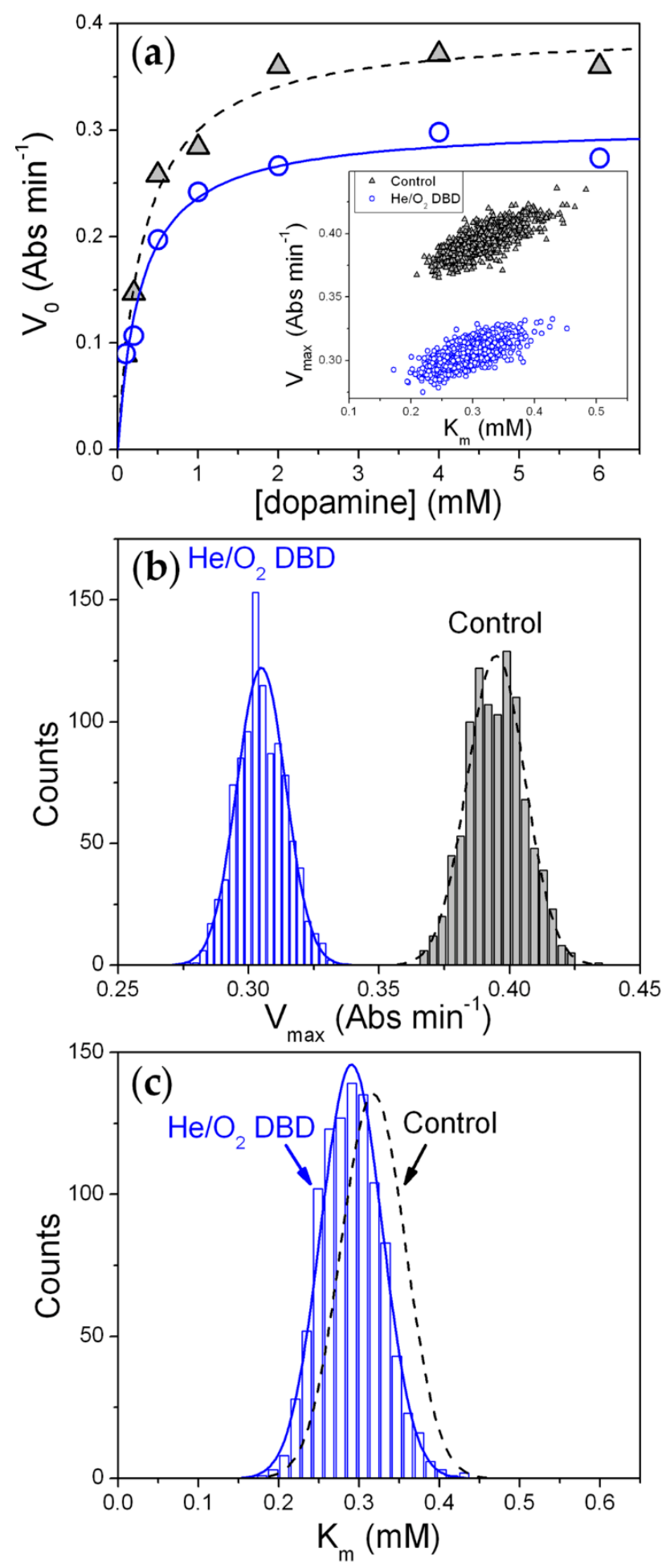

Figure 5. (a) Initial rate as a function of the dopamine concentration obtained for $5 \mu \mathrm{g}$ of tyrosinase redissolved in buffer solution after drying (i.e., control sample; grey triangle) and after drying and exposure to $\mathrm{He} / 1 \% \mathrm{O}_{2} \mathrm{DBD}$ for $30 \mathrm{~min}$ (blue circle); lines correspond to the fit to Equation (1). The results from 1000 runs of Monte Carlo analysis of best-fit data in panel (a) are shown in the inset of panel (a) (correlation between the $\mathrm{V}_{\max }$ and $\mathrm{K}_{\mathrm{m}}$ best-fit values), in panel (b) (frequency of the $\mathrm{V}_{\max }$ ), and in panel (c) (frequency of the Michaelis constant, $K_{m}$ ).

Kinetic results confirm that Tyr activity reduction is greater than the thickness loss of the Tyr deposit. Moreover, the analysis of the impact of the oxygen-containing plasma on $\mathrm{K}_{\mathrm{m}}$ reveals that 
no significant reduction of the enzyme affinity for the substrate occurs upon plasma exposure, i.e., the fraction of residual Tyr which is still functional after plasma exposure shows unchanged substrate affinity. On the other hand, there is a certain fraction of residual enzyme, which while not removed through etching, is fully inactivated by the AP plasma. Considering that, after $60 \mathrm{~min}$ of exposure to the $\mathrm{He} / 1 \% \mathrm{O}_{2}$ fed DBD, the residual thickness slightly decreases to $\sim 90 \%$, while residual activity drops to $\sim 65 \%$ (Figure 2), the fraction of enzyme inactivated by plasma exposure can be roughly quantified as $25 \%$. To further investigate tyrosinase behavior, the surface chemical composition of the enzyme deposits was analyzed by XPS before and after $30 \mathrm{~min}$ exposure to the $\mathrm{He} / 1 \% \mathrm{O}_{2}$ fed DBD. Table 2 shows that plasma interaction with the dry Tyr deposit leads to the increase of the oxygen surface atomic concentration and consequent reduction of the carbon atomic percentage, while nitrogen surface concentration does not change significantly. Sulfur atomic percentage remains very low (1 at \%); however, it is worth to note that the $\mathrm{S} 2 \mathrm{p}$ signal is centered at $162.5 \mathrm{eV}$ for the pristine sample, as typical for C-S and S-S moieties, and shifts to $168.5 \mathrm{eV}$ upon plasma exposure due to sulfur oxidation (e.g., sulfates and sulfonates formation) [60]. Interestingly, in addition to surface oxidation, considerable increase of XPS atomic concentrations of $\mathrm{Na}, \mathrm{K}$, and $\mathrm{P}$ is observed. This increase can be explained considering that these atomic species, present as contaminants in the pristine Tyr deposit, cannot be etched away by the oxygen-containing plasma. As reported in the literature on low pressure and atmospheric pressure plasma etching of dry proteins (e.g., bovine serum albumin [40,60]), the building up of inorganic compounds at the surface of protein deposits can provide passivation effect and limit the action of reactive oxygen species present in the plasma in terms of etching efficiency. Interestingly, the fact that the total concentration of $\mathrm{Na}, \mathrm{K}, \mathrm{P}$, and $\mathrm{S}$ significantly increases from 1.5 to 11.5 at $\%$ after 30 min of plasma exposure (Table 2), and that both residual thickness and activity do not decrease appreciably when process duration exceeds $30 \mathrm{~min}$ (Figure 3a), suggests that the formation on the deposit surface of a layer enriched in inorganic compounds protects Tyrosinase from further etching and damage.

Table 2. XPS surface atomic concentrations of the dry Tyr deposit before and after $30 \mathrm{~min}$ exposure to the DBD fed with $\mathrm{He} / 1 \% \mathrm{O}_{2}$ mixture ( $\left.\mathrm{f}=20 \mathrm{kHz}, \mathrm{V}_{\mathrm{a}}=1.1 \mathrm{kV} \mathrm{V}_{\mathrm{rms}}\right)$.

\begin{tabular}{lcccccc}
\hline & $\begin{array}{c}\mathbf{C} \\
\text { at } \%\end{array}$ & $\begin{array}{c}\mathbf{O} \\
\text { at } \%\end{array}$ & $\begin{array}{c}\mathbf{N} \\
\text { at } \%\end{array}$ & $\begin{array}{c}\mathbf{S} \\
\text { at } \%\end{array}$ & $\begin{array}{c}\mathbf{P} \\
\text { at } \%\end{array}$ & $\begin{array}{c}\mathbf{K}, \mathbf{N a} \\
\text { at } \%\end{array}$ \\
\hline Pristine Tyr - control & 64 & 26 & 8.5 & 0.5 & - & 1.0 \\
Tyr - He/1\% $\mathrm{O}_{2}$ DBD & 44 & 37 & 7.5 & 1.0 & 3.0 & 7.5 \\
\hline
\end{tabular}

The curve fitting of the high-resolution XPS C 1s spectra (Table 3, Figure 6) shows that $\mathrm{O}_{2}$-containing plasma exposure induces a decrease of the peak area percentages of the hydrocarbon C-C/C-H and $\mathrm{C}-\mathrm{N} / \mathrm{C}-\mathrm{O}$ components (as a whole, 10\% decrease), a slight increase of the percentage of the component due to $\mathrm{C}=\mathrm{O}, \mathrm{N}-\mathrm{C}=\mathrm{O}$, and $\mathrm{O}-\mathrm{C}-\mathrm{O}$ groups as well as the appearance of a new peak ascribed to $\mathrm{COO}$ functionalities (289.0 eV, $7 \%$ ) [35,40,51]. The high-resolution XPS N 1s signal of Tyr shows minor changes after plasma exposure [61], while in case of the $\mathrm{O} 1 \mathrm{~s}$ spectrum it is possible to observe a considerable increase of the low binding energy component, ascribed for instance to $\mathrm{O}=\mathrm{C}$ moieties (Figure S4, Table S1). 

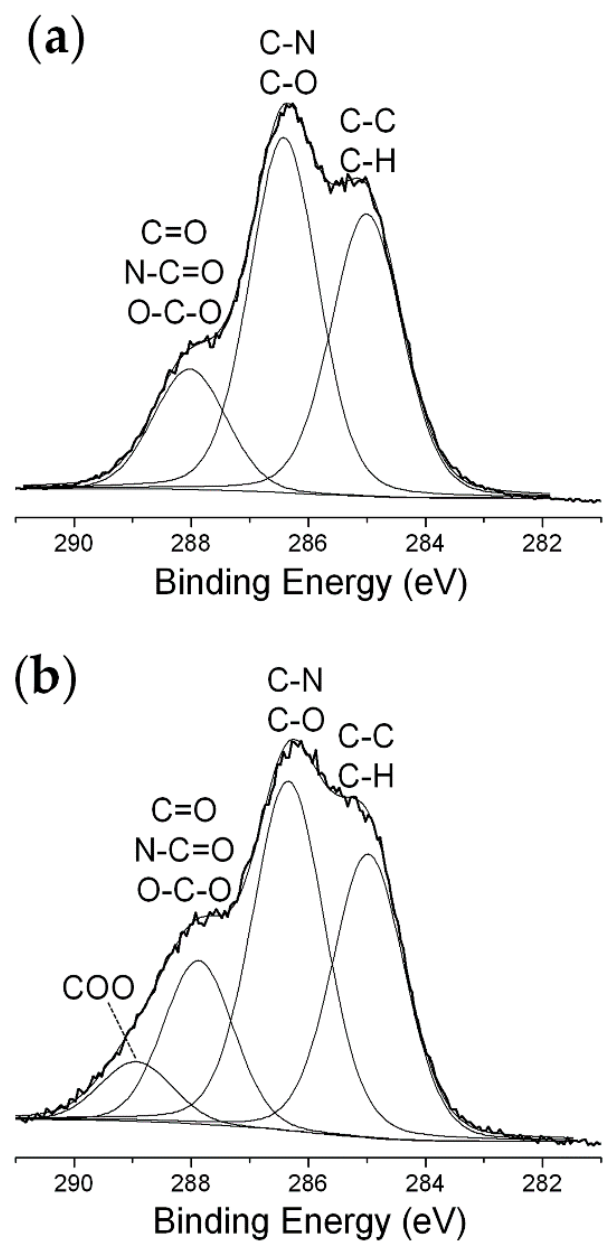

Figure 6. High-resolution X-ray photoelectron spectroscopy (XPS) C 1s spectra of a $5 \mu \mathrm{g}$ Tyr deposit (a) before and (b) after exposure to a DBD fed with $\mathrm{He} / 1 \% \mathrm{O}_{2}$ mixture for $30 \mathrm{~min}(\mathrm{f}=20 \mathrm{kHz}$, $\mathrm{V}_{\mathrm{a}}=1.1 \mathrm{kV} \mathrm{rms}_{\mathrm{rm}}$.

Table 3. Curve fitting results of high-resolution C 1s XPS spectra of the dry Tyr deposit before and after 30 min exposure to the DBD fed with $\mathrm{He} / 1 \% \mathrm{O}_{2}$ mixture $\left(\mathrm{f}=20 \mathrm{kHz}, \mathrm{V}_{\mathrm{a}}=1.1 \mathrm{kV}_{\mathrm{rms}}\right)$.

\begin{tabular}{ccccc}
\hline & $\begin{array}{c}\text { C-C/C-H } \\
\text { Peak Area \% }\end{array}$ & $\begin{array}{c}\text { C-N/C-O } \\
\text { Peak Area \% }\end{array}$ & $\begin{array}{c}\text { C=O/N-C=O/O-C-O } \\
\text { Peak Area \% }\end{array}$ & $\begin{array}{c}\text { COO } \\
\text { Peak Area \% }\end{array}$ \\
\hline & $285.0 \pm 0.2 \mathrm{eV}$ & $286.3 \pm 0.2 \mathrm{eV}$ & $288.1 \pm 0.2 \mathrm{eV}$ & $289.0 \pm 0.2 \mathrm{eV}$ \\
\hline Pristine Tyr - control & 37 & 46 & 17 & - \\
Tyr - He $/ 1 \% \mathrm{O}_{2}$ DBD & 32 & 41 & 20 & 7 \\
\hline
\end{tabular}

\subsection{Enzyme Overcoating by a Plasma-Deposited Polyethylene-Like Film}

DBDs fed with helium-ethylene mixtures allow depositing a uniform polyethylene-like coating on the dry enzyme [35]. This coating is hydrophobic (static water contact angle of $\sim 100^{\circ}$ ) and acts as an efficient barrier, precluding the release of the enzyme upon immersion in buffer solution. When the polyethylene-like film is gently scratched, the release of the underneath enzyme is allowed and the enzyme-catalyzed reaction is immediately initiated.

The effect of PECVD from ethylene-containing DBDs on the activity of the enzyme was evaluated by varying various process parameters, such as the applied voltage $\left(0.85\right.$ and $\left.1.1 \mathrm{kV}_{\mathrm{rms}}\right)$, the ethylene concentration in the feed mixture (from 0.1 to $1.0 \%$ ), and the deposition time (10 and $30 \mathrm{~min}$ ).

The exposure time turned out to be a critical parameter for preserving Tyr functionality $(5 \mu \mathrm{g}$ Tyr amount). More specifically, Figure 7 shows that exposure to $\mathrm{He} / \mathrm{C}_{2} \mathrm{H}_{4}$ fed DBDs for 30 min decreases Tyr 
residual activity to $\sim 80 \%$, independently from both the applied voltage and the ethylene concentration in the feed mixture. However, the reduction of the PECVD process duration to $10 \mathrm{~min}$, at an applied voltage of $0.85 \mathrm{kV}_{\mathrm{rms}}$, allows fully preserving Tyr activity.

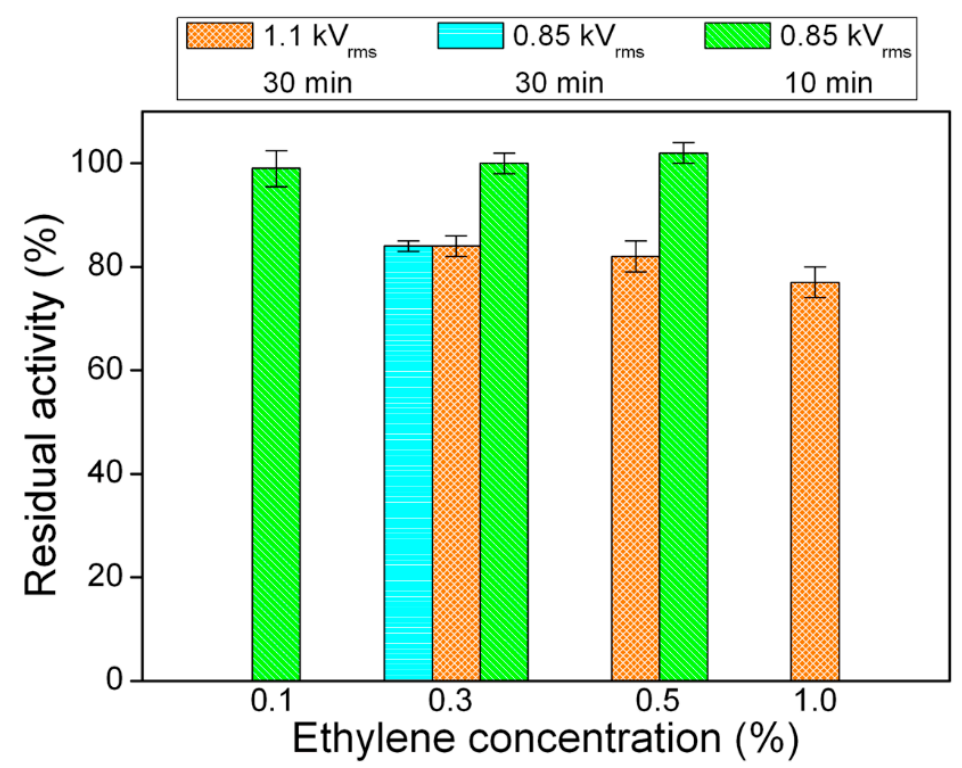

Figure 7. Residual activity of Tyr $(5 \mu \mathrm{g})$ after exposure to $\mathrm{He} / \mathrm{C}_{2} \mathrm{H}_{4}$ fed DBDs under different processing conditions $\left(\mathrm{V}_{\mathrm{a}}=0.85,1.1 \mathrm{kV}_{\mathrm{rms}} ;\left[\mathrm{C}_{2} \mathrm{H}_{4}\right]=0.1,0.3,0.5,1 \% ; \mathrm{t}=10,30 \mathrm{~min}\right)$.

It is worth specifying that:

- The ethylene concentration in the feed mixture mainly influences the deposition rate of the coating. For instance, the DR increases from $\sim 20$ to $\sim 30 \mathrm{~nm} \cdot \mathrm{min}^{-1}$ by increasing $\left[\mathrm{C}_{2} \mathrm{H}_{4}\right]$ from $0.1 \%$ to $0.5 \%$, at fixed applied voltage of $0.85 \mathrm{kV}_{\text {rms }}$ (Table S2).

- The increase of the applied voltage leads to increased specific power dissipated by the plasma and slightly greater deposition rate (Table 1 and Table S2).

Considering the DR values reported in Table S2 as well as the deposition times used in the experiments (10 and $30 \mathrm{~min}$, Table 1), the average thickness of the hydrocarbon coating deposited on Tyr ranges between $230 \pm 10$ and $1290 \pm 60 \mathrm{~nm}$. After thin film deposition, the surface chemical composition of the samples, as determined by XPS, is dominated by the hydrocarbon polymer. Specifically, the carbon surface atomic concentration is very high $(\sim 98 \%)$, while oxygen percentage remains very low $(\sim 2 \%)$. In addition, the high-resolution XPS C 1s signal (Figure S5) can be curve-fitted with the main aliphatic hydrocarbon component $(\mathrm{C}-\mathrm{C} / \mathrm{C}-\mathrm{H})$ at $285.0 \mathrm{eV}$ and the very weak peak due to $\mathrm{C}-\mathrm{O}(286.5 \mathrm{eV})$. These results can be explained considering that in all experiments the thickness of the polyethylene-like coating deposited on Tyr is considerably greater than the maximum sampling depth of XPS ( 10 nm), therefore no contributions from the underneath enzyme would be expected.

The DBD regime does not seem to significantly influence residual activity results. In this regard, it is worth reminding that at the applied voltage of $1.1 \mathrm{kV}_{\mathrm{rms}}$, the discharge operates in homogeneous regime when the ethylene concentration is lower or equal to $0.5 \%$, while a filamentary DBD is obtained for greater values of $\left[\mathrm{C}_{2} \mathrm{H}_{4}\right]$ (i.e., $1 \%$ ). Interestingly, Figure 7 shows that a very similar decrease in Tyr activity occurs after $30 \mathrm{~min}$ deposition at $1.1 \mathrm{kV}_{\mathrm{rms}}$, regardless the ethylene concentration and therefore the DBD regime.

\subsection{Exposure of Dry Enzymes to DBDs: Comparison between Tyr and GOx}

The aim of this section is to compare results obtained for tyrosinase, with data previously reported for glucose oxidase under identical plasma processing conditions (Table 1) [35]. This comparison allows 
enlightening similarities and differences between the two enzymes, obtaining a more general picture of the effect of various plasma environments and processing conditions, and finally drawing some conclusions on how experimental parameters can be optimized to achieve increased retention of enzyme activity. Table 4 compares residual activity results for GOx and Tyr after selected plasma processes.

Table 4. Tyr and GOx residual activity after selected plasma processes (complete plasma processing conditions are reported in Table 1). GOx data are taken from Ref. [35].

\begin{tabular}{|c|c|c|c|c|c|c|}
\hline & & & $\begin{array}{l}\text { Tyr } \\
2 \mu \mathrm{g}\end{array}$ & $\begin{array}{l}\text { Tyr } \\
5 \mu \mathrm{g}\end{array}$ & $\begin{array}{l}\text { GOx } \\
30 \mu g\end{array}$ & $\begin{array}{c}\text { GOx } \\
100 \mu g\end{array}$ \\
\hline Feed Mixture & $\begin{array}{c}V_{\mathrm{a}} \\
\left(\mathrm{kV}_{\mathrm{rms}}\right)\end{array}$ & $\begin{array}{c}t \\
(\mathrm{~min})\end{array}$ & $\begin{array}{c}\text { Res. } \\
\text { Activity (\%) }\end{array}$ & $\begin{array}{c}\text { Res. } \\
\text { Activity (\%) }\end{array}$ & $\begin{array}{c}\text { Res. } \\
\text { Activity (\%) }\end{array}$ & $\begin{array}{c}\text { Res. } \\
\text { Activity (\%) }\end{array}$ \\
\hline $\mathrm{He}$ & 1.10 & 30 & $85 \pm 4$ & $83 \pm 4$ & $95 \pm 6$ & $100 \pm 6$ \\
\hline $\mathrm{He} / 1 \% \mathrm{O}_{2}$ & 1.10 & 30 & $70 \pm 5$ & $67 \pm 2$ & $14.0 \pm 1.0$ & $85 \pm 2$ \\
\hline $\mathrm{He} / 0.3 \% \mathrm{C}_{2} \mathrm{H}_{4}$ & 1.10 & 30 & - & $84 \pm 2$ & $96 \pm 3$ & - \\
\hline $\mathrm{He} / 0.3 \% \mathrm{C}_{2} \mathrm{H}_{4}$ & 0.85 & 30 & - & $84.0 \pm 1.0$ & $101 \pm 2$ & - \\
\hline $\mathrm{He} / 0.3 \% \mathrm{C}_{2} \mathrm{H}_{4}$ & 0.85 & 10 & - & $100 \pm 2$ & $100 \pm 2$ & - \\
\hline
\end{tabular}

First of all, among the investigated plasma environments, the use of a $\mathrm{He} / 1 \% \mathrm{O}_{2}$ feed mixture is found to have the highest impact on the activity of both enzymes, as described below:

- Tyrosinase. Considerable retention of Tyr activity is observed also when very low enzyme amounts are exposed to the plasma, with weak dependence on both the enzyme exposed amount and the process duration. The $\mathrm{He} / 1 \% \mathrm{O}_{2}$ fed DBD appreciably affects Tyr activity when the exposed amount is below $10 \mu \mathrm{g}$ (Figure 2). For $5 \mu \mathrm{g}$ of dry Tyr, residual activity drops to $\sim 65 \%$ after $30 \mathrm{~min}$ and remains constant for longer exposure times (Figure 3a). After $60 \mathrm{~min}$ of exposure to the $\mathrm{O}_{2}$-containing DBD, the $5 \mu \mathrm{g}$ Tyr deposit shows an average thickness loss of a few hundred $\mathrm{nm}$, corresponding to a residual thickness of $\sim 90 \%$ (Figures $3 \mathrm{a}$ and $4 \mathrm{c}$ ). This is consistent with a remarkable etching resistance of Tyr deposits. Both residual activity and thickness decrease with exposure time (Figure 3a); however, residual thickness values remain greater than the corresponding values of residual activity. In this regard, it is found that, after plasma exposure, the major fraction of the residual enzyme exhibits unchanged functionality and substrate affinity (i.e., the slight decrease in $\mathrm{M}-\mathrm{M}$ constant is found to not be statistically relevant as shown in Figure 5c), while a minor fraction is fully inactivated. The oxygen-containing DBD leads to the formation on the deposit surface of a layer enriched in inorganic compounds. This layer seems to protect tyrosinase from etching and functional damage, limiting the reduction in Tyr activity with exposure time.

- Glucose oxidase. Also for GOx it is possible to identify a threshold value of exposed amount, below which the $\mathrm{He} / 1 \% \mathrm{O}_{2}$ fed DBD has an appreciable impact on enzyme activity. However, in case of GOx, this threshold value is found to be $150 \mu \mathrm{g}$ [35], i.e., fifteen times greater than that of Tyr. Moreover, a remarkable decrease in GOx residual activity is observed when the exposed amount is reduced; for instance, after $30 \mathrm{~min}$ plasma exposure, residual activity steeply decreases from $85 \%$ to less than $5 \%$ by decreasing the exposed amount from 100 to $10 \mu \mathrm{g}$. Figure 3 a represents a fair comparison between the two enzymes, because although the GOx amount used in the experiments is larger $(30 \mu \mathrm{g})$, it spreads uniformly on a larger area $\left(8.55 \mathrm{~mm}^{2}\right)$ so that the effective protein surface density $\left(3.51 \mu \mathrm{g} \cdot \mathrm{mm}^{-2}\right)$ is very close to the surface density of Tyr in the coffee-ring $\left(3.27 \mu \mathrm{g} \cdot \mathrm{mm}^{-2}\right)$. It is clear from Figure 3a that GOx residual activity more significantly decreases with exposure time, and is lower than that of Tyr. On the other hand, when GOx amount is $100 \mu \mathrm{g}$ (i.e., a thicker enzyme deposit is exposed to the plasma), residual activity slightly decreases to $\sim 85 \%$ after $10 \mathrm{~min}$ and remains constant for longer exposure times. Interestingly, in case of GOx, very good agreement is found between the values of the residual activity and residual thickness (Figure 3a). Therefore, the loss in GOx activity upon exposure to the $\mathrm{He} / 1 \% \mathrm{O}_{2}$ fed DBD 
seems to be directly correlated to the deposit thickness decrease due to etching. Moreover, it is worth mentioning that the thickness of a $30 \mu \mathrm{g}$ GOx deposit decreases by $\sim 3 \mathrm{~m}$ after $60 \mathrm{~min}$ exposure to the $\mathrm{O}_{2}$-containing plasma, similarly to the polyethylene-like coating. Also for $\mathrm{GOx}$, the chemical modification of the deposit surface upon plasma exposure leads to the formation of a protective layer with strong ablation resistance, which progressively reduces the etching rate with increasing the exposure time [35]. Specifically, XPS results show that the $\mathrm{O}_{2}$-containing DBD causes a decrease of both $\mathrm{C}$ and $\mathrm{N}$ surface atomic concentrations as well as considerable increase of the atomic percentages of $\mathrm{O}, \mathrm{K}$, and $\mathrm{Na}$ [35]. The GOx kinetic response to the $\mathrm{O}_{2}$-containing plasma is different from that shown by Tyr in similar conditions. As reported in our previous paper [35], after GOx exposure to the $\mathrm{He} / 1 \% \mathrm{O}_{2}$ fed DBD: (i) the decrease in $\mathrm{V}_{\max }$ (in agreement with the observed reduction in activity) corresponds to the thickness loss of the deposit, accounting for enzyme removal by plasma etching; (ii) an increase in $\mathrm{K}_{\mathrm{m}}$ is observed, suggesting that the plasma reduces the affinity for the substrate of the still functional enzyme.

It can be, therefore, concluded that the trends observed for the two enzymes are rather similar; however, in the case of Tyr it is possible to use much smaller enzyme amounts, while maintaining greater values of both residual activity and residual thickness. GOx is much more sensitive than Tyr to the $\mathrm{He} / 1 \% \mathrm{O}_{2}$ fed DBD in terms of both protein removal through plasma etching and loss in activity and substrate affinity.

It is not trivial to explain this evidence; however, the following factors could contribute to the diverse enzyme response: (i) the different chemical structure of the two enzymes, considering that, for instance, the glycosylated structure of GOx could be more sensitive to chemical reactions occurring in the plasma, and in turn, be more prone to plasma etching; (ii) the presence of slightly different inorganic contaminations in the dry deposits, which could lead to the formation of a protective layer in different exposure times and with different composition (and likely different passivation efficacy); (iii) the morphology of the dry enzyme deposit. This last point deserves further discussion. Figure $3 b$ clearly shows the very different structure of the Tyr and GOx dry deposits. While a ring-shaped structure is obtained for Tyr, the drying of the GOx solution drop on the glass slide leads to a uniform and roughly circular deposit with a diameter of $3.3 \pm 0.4 \mathrm{~mm}$ (Figure 3b). Since GOx distributes over a larger area compared to Tyr, a greater fraction of the GOx exposed amount is expected to interact with the plasma. This could, at least partially, explain the more significant and comparable reduction of residual activity and thickness observed for GOx. In case of Tyr, the formation of a coffee-ring structure, leads to a reduced surface area of the deposit exposed to plasma, reasonably limiting the extent of the plasma-enzyme interaction. Even if, it is not possible to exclude that thickness loss may be underestimated in case of Tyr, due to the fact that etching mainly occurs at the outer and inner rims and in the cracks of the coffee-ring structure (Figure 4), WLVSI images clearly evidence the greater etching resistance of Tyr deposits with respect to GOx ones [35].

The above discussion suggests that enhanced retention of enzyme activity in $\mathrm{He} / \mathrm{O}_{2}$ fed DBDs could be achieved in different ways: (i) by increasing the amount of exposed enzyme, and therefore, the initial thickness of the enzyme deposit (as reported in Ref. [35]); (ii) by acting on the morphology of the protein deposit and guiding, when possible, the formation of a coffee-ring structure; this latter allows reducing plasma-enzyme interaction and increasing deposit thickness, while keeping fixed the enzyme amount used in the experiments; (iii) by incorporating in the enzyme deposits very low amounts of inorganic compounds with strong resistance against plasma etching.

Results obtained in case of $\mathrm{He} / \mathrm{C}_{2} \mathrm{H}_{4}$ fed DBDs show that the activity of both enzymes is not considerably affected by PECVD process conditions (Table 4). In particular, the residual activity of Tyr and GOx remains greater than $\sim 80 \%$ and $\sim 90 \%$, respectively. Enzyme activity can be fully preserved by decreasing the applied voltage to $0.85 \mathrm{kV}_{\mathrm{rms}}$ and the exposure time to $10 \mathrm{~min}$. These outcomes allow envisaging the possibility of using PECVD at atmospheric pressure for enzyme immobilization by overcoating, with considerable retention of enzyme functionality upon plasma exposure. 
Finally, activity of both Tyr and GOx is barely affected by direct exposure to DBDs fed with pure helium (Table 4). This evidence suggests that the chemical environment generated in the plasma, due to the presence of reactive additives in the feed mixture, could play a major role in the direct interaction of DBDs with dry enzymes.

\section{Conclusions}

The direct interaction of dry tyrosinase with atmospheric pressure DBDs fed with helium, helium/oxygen, and helium/ethylene mixtures was investigated to provide a comprehensive picture of plasma effects on Tyr over a range of chemical environments and processing conditions typically used in surface modification.

First of all, results show good retention of Tyr activity also when very low enzyme amounts are exposed to the plasma $(<10 \mu \mathrm{g})$, with a slight dependence on the exposed amount and exposure time. For $5 \mu \mathrm{g}$ of Tyr, an appreciable decrease in enzyme activity is observed upon exposure to oxygen-containing DBD due to both enzyme etching and damage. Nevertheless, Tyr deposits display remarkable etching resistance, reasonably conferred by plasma-induced changes in their surface chemical composition and by their coffee-ring structure. In particular, XPS results show that exposure to $\mathrm{He} / 1 \% \mathrm{O}_{2}$ fed DBD leads to the formation of a surface layer enriched in inorganic compounds, which limits Tyrosinase etching and damage. Ethylene-containing DBDs allow coating Tyr with a hydrocarbon polymer film, in order to obtain its immobilization. It is found that Tyr activity can be fully preserved by properly adjusting PECVD process conditions. All these findings, along with previous data obtained for GOx, enlighten a high stability of dry enzymes in various plasma environments and emphasize the need for optimal selection of processing conditions. Future work will involve extending our investigations to a less expensive main gas (e.g., argon or nitrogen rather than helium), taking due account of the fact that plasma characteristics and optimal processing conditions inevitably change as a function of the main gas utilized.

Overall, this study suggests new opportunities for the use of atmospheric pressure non-equilibrium plasmas in enzyme immobilization strategies. For instance, in multi-step immobilization procedures AP plasma-based processes could be exploited for enzyme overcoating, interface modification, and surface cleaning, with considerable retention of enzyme activity upon plasma exposure.

Supplementary Materials: The following are available online at http:/www.mdpi.com/1996-1944/13/9/2181/s1, Figure S1: voltage and current signals of $(\mathbf{a})$ a pure $\mathrm{He} \mathrm{DBD}$ and $(\mathbf{b})$ a $\mathrm{He} / 1 \% \mathrm{O} 2 \mathrm{fed} \mathrm{DBD}(\mathrm{f}=20 \mathrm{kHz}, \mathrm{Va}=1.1$ kVrms), Figure S2: voltage and current signals of $\mathrm{He} / \mathrm{C}_{2} \mathrm{H}_{4}$ fed DBDs generated at $20 \mathrm{kHz}$ under different experimental conditions (Table 1): (a) $\left[\mathrm{C}_{2} \mathrm{H}_{4}\right]=0.3 \%, \mathrm{~V}_{\mathrm{a}}=0.85 \mathrm{kV}_{\mathrm{rms}}$; (b) $\left[\mathrm{C}_{2} \mathrm{H}_{4}\right]=0.3 \%, \mathrm{~V}_{\mathrm{a}}=1.1 \mathrm{kV}$ rms; (c) $\left[\mathrm{C}_{2} \mathrm{H}_{4}\right]=1 \%, \mathrm{~V}_{\mathrm{a}}=1.1 \mathrm{kV}_{\mathrm{rms}}$, Figure S3: residual activity of tyrosinase ( 2 and $5 \mu \mathrm{g}$ ) exposed to DBDs fed with He and $\mathrm{He} / 1 \% \mathrm{O}_{2}$ mixture as a function of the exposure time, Figure S4: high-resolution XPS C $1 \mathrm{~s}, \mathrm{O} 1 \mathrm{~s}$ and $\mathrm{N} 1 \mathrm{~s}$ spectra of a $5 \mu \mathrm{g}$ Tyr deposit before and after exposure to a DBD fed with $\mathrm{He} / 1 \% \mathrm{O}_{2}$ mixture for $30 \mathrm{~min}$, Table S1: curve fitting results of high-resolution $\mathrm{C} 1 \mathrm{~s}, \mathrm{O} 1 \mathrm{~s}$ and $\mathrm{N} 1 \mathrm{~s}$ XPS spectra of a $5 \mu \mathrm{g}$ Tyr deposit before and after $30 \mathrm{~min}$ exposure to the DBD fed with $\mathrm{He} / 1 \% \mathrm{O}_{2}$ mixture, Table S2: deposition rate (DR) of the polyethylene-like coating under the PECVD conditions investigated in the present work, Figure S5: high-resolution XPS C 1s spectrum of the polyethylene-like coating deposited on Tyr $(5 \mu \mathrm{g})$ by using a $\mathrm{He} / 0.1 \% \mathrm{C}_{2} \mathrm{H}_{4}$ fed DBD ( $\mathrm{f}=20 \mathrm{kHz}, \mathrm{V}_{\mathrm{a}}=0.85 \mathrm{kV}$ rms, $\mathrm{t}=10 \mathrm{~min}$, thickness of the coating $=230 \pm 10 \mathrm{~nm}$ ).

Author Contributions: Conceptualization and methodology, G.P., A.M., F.F. (Francesco Fracassi), and F.F. (Fiorenza Fanelli); investigation, A.L., V.A. (Valeria Angarano), V.A. (Vincenza Armenise), A.M., and F.F. (Fiorenza Fanelli); formal analysis, G.P.; data curation and validation, A.M. and F.F. (Fiorenza Fanelli); visualization, A.L.; resources and funding acquisition, G.P. and F.F. (Francesco Fracassi); writing-original draft preparation, A.L., A.M., G.P., F.F. (Francesco Fracassi), and F.F. (Fiorenza Fanelli); writing-review and editing, F.F. (Fiorenza Fanelli), G.P., and A.M.; project administration and supervision, G.P., A.M., and F.F. (Fiorenza Fanelli) All authors have read and agreed to the published version of the manuscript.

Funding: This research was funded by the Ministero dell'Istruzione, dell'Università e della Ricerca (MIUR), grant number PONa3_00369 - “Laboratorio SISTEMA", and by Regione Puglia, grant number 51 - "LIPP” within the Framework Programme Agreement APQ "Ricerca Scientifica", II atto integrativo - Reti di Laboratori Pubblici di Ricerca.

Acknowledgments: Teresa Lasalandra and Savino Cosmai are gratefully acknowledged for the skillful technical assistance. 
Conflicts of Interest: The authors declare no conflicts of interest.

\section{References}

1. Otte, K.B.; Hauer, B. Enzyme engineering in the context of novel pathways and products. Curr. Opin. Biotech. 2015, 35, 16-22. [CrossRef] [PubMed]

2. Kurbanoglu, S.; Erkmen, C.; Uslu, B. Frontiers in electrochemical enzyme based biosensors for food and drug analysis. TRAC-Trends Anal. Chem. 2020, 124, 115809. [CrossRef]

3. Nguyen, H.H.; Lee, S.H.; Lee, U.J.; Fermin, C.D.; Kim, M. Immobilized enzymes in biosensor applications. Materials 2019, 12, 121. [CrossRef] [PubMed]

4. Romero-Fernández, M.; Paradisi, F. Protein immobilization technology for flow biocatalysis. Curr. Opin. Chem. Biol. 2020, 55, 1-8. [CrossRef] [PubMed]

5. Boudrant, J.; Woodley, J.M.; Fernandez-Lafuente, R. Parameters necessary to define an immobilized enzyme preparation. Process Biochem. 2020, 90, 66-80. [CrossRef]

6. Mohamad, N.R.; Marzuki, N.H.C.; Buang, N.A.; Huyop, F.; Wahab, R.A. An overview of technologies for immobilization of enzymes and surface analysis techniques for immobilized enzymes. Biotechnol. Biotechnol. Equip. 2015, 29, 205-220. [CrossRef]

7. Zhang, Y.; Ge, J.; Liu, Z. Enhanced activity of immobilized or chemically modified enzymes. ACS Catal. 2015, 5, 4503-4513. [CrossRef]

8. Geor malar, C.; Seenuvasan, M.; Kumar, K.S.; Kumar, A.; Parthiban, R. Review on surface modification of nanocarriers to overcome diffusion limitations: An enzyme immobilization aspect. Biochem. Eng. J. 2020, 158, 107574. [CrossRef]

9. Mallardi, A.; Angarano, V.; Magliulo, M.; Torsi, L.; Palazzo, G. General approach to the immobilization of glycoenzyme chains inside calcium alginate beads for bioassay. Anal. Chem. 2015, 87, 11337-11344. [CrossRef]

10. Li, J.; Ma, J.; Jiang, T.; Wang, Y.; Wen, X.; Li, G. Constructing biopolymer-inorganic nanocomposite through a biomimetic mineralization process for enzyme immobilization. Materials 2015, 8, 6004-6017. [CrossRef]

11. Romero-Arcos, M.; Garnica-Romo, M.G.; Martínez-Flores, H.E. Electrochemical study and characterization of an amperometric biosensor based on the immobilization of laccase in a nanostructure of $\mathrm{TiO}_{2}$ synthesized by the sol-gel method. Materials 2016, 9, 543. [CrossRef] [PubMed]

12. Dong, W.; Wang, K.; Chen, Y.; Li, W.; Ye, Y.; Jin, S. Construction and characterization of a chitosan-immobilized-enzyme and $\beta$-cyclodextrin-included-ferrocene-based electrochemical biosensor for $\mathrm{H}_{2} \mathrm{O}_{2}$ detection. Materials 2017, 10, 868. [CrossRef] [PubMed]

13. Jankowska, K.; Ciesielczyk, F.; Bachosz, K.; Zdarta, J.; Kaczorek, E.; Jesionowski, T. Laccase immobilized onto zirconia-slica hybrid doped with $\mathrm{Cu}^{2+}$ as an effective biocatalytic system for decolorization of dyes. Materials 2019, 12, 1252. [CrossRef] [PubMed]

14. Aslanli, A.; Stepanov, N.; Razheva, T.; Podorozhko, E.A.; Lyagin, I.; Lozinsky, V.I.; Efremenko, E. Enzymatically functionalized composite materials based on nanocellulose and poly(vinyl alcohol) cryogel and possessing antimicrobial activity. Materials 2019, 12, 3619. [CrossRef] [PubMed]

15. Apetrei, I.M.; Apetrei, C. Development of a novel biosensor based on tyrosinase/platinum nanoparticles/chitosan/graphene nanostructured layer with applicability in bioanalysis. Materials 2019, 12, 1009. [CrossRef] [PubMed]

16. Wee, Y.; Park, S.; Kwon, Y.H.; Ju, Y.; Yeon, K.M.; Kim, J. Tyrosinase-immobilized CNT based biosensor for highly-sensitive detection of phenolic compounds. Biosens. Bioelectron. 2019, 132, 279-285. [CrossRef]

17. Elagli, A.; Belhacene, K.; Vivien, C.; Dhulster, P.; Froidevaux, R.; Supiot, P.J. Facile immobilization of enzyme by entrapment using a plasma-deposited organosilicon thin film. Mol. Catal. B 2014, 110, 77-86. [CrossRef]

18. Shi, J.; Tian, Y.; Liu, H.; Yang, D.; Zhang, S.; Wu, Y.; Jiang, Z. Shielding of enzyme by a stable and protective organosilica layer on monolithic Scaffolds for Continuous Bioconversion. Ind. Eng. Chem. Res. 2017, 56, 10615-10622. [CrossRef]

19. Muguruma, H.; Kase, Y. Structure and biosensor characteristics of complex between glucose oxidase and plasma-polymerized nanothin film. Biosens. Bioelectron. 2006, 22, 737-743. [CrossRef] [PubMed] 
20. Belhacene, K.; Elagli, A.; Vivien, C.; Treizebré, A.; Dhulster, P.; Supiot, P.; Froidevaux, R. Investigation of the effect of plasma polymerized siloxane coating for enzyme immobilization and microfluidic device conception. Catalysts 2016, 6, 209. [CrossRef]

21. Wieland, F.; Bruch, R.; Bergmann, M.; Partel, S.; Urban, G.A.; Dincer, C. Enhanced protein immobilization on polymers - A plasma surface activation study. Polymers 2020, 12, 104. [CrossRef] [PubMed]

22. Bax, D.V.; Yin, Y.; Kondyurin, A.; Diwan, A.D.; Bhargav, D.; Weiss, A.S.; Bilek, M.M.M.; McKenzie, D.R. Plasma processing of PDMS based spinal implants for covalent protein immobilization, cell attachment and spreading. J. Mater. Sci. Mater. Med. 2018, 29, 178. [CrossRef] [PubMed]

23. Liao, L.; Meng, Y.; Wang, R.; Jia, B.; Li, P. Coupling and regulation of porous carriers using plasma and amination to improve the catalytic performance of glucose oxidase and catalase. Front. Bioeng. Biotechnol. 2019, 7, 426. [CrossRef] [PubMed]

24. Coad, B.R.; Scholz, T.; Vasilev, K.; Hayball, J.D.; Short, R.D.; Griesser, H.J. Functionality of proteins bound to plasma polymer surfaces. ACS Appl. Mater. Interfaces 2012, 4, 2455-2463. [CrossRef] [PubMed]

25. Ghasemi, M.; Minier, M.J.G.; Tatoulian, M.; Chehimi, M.M.; Arefi-Khonsari, F. Ammonia plasma treated polyethylene films for adsorption or covalent immobilization of trypsin: Quantitative correlation between X-ray photoelectron spectroscopy data and enzyme activity. J. Phys. Chem. B 2011, 115, 10228-10238. [CrossRef] [PubMed]

26. Muguruma, H.; Hoshino, T.; Nowaki, K. Electronically type-sorted carbon nanotube-based electrochemical biosensors with glucose oxidase and dehydrogenase. ACS Appl. Mater. Interfaces 2015, 7, 584-592. [CrossRef]

27. Fanelli, F.; Fracassi, F. Atmospheric pressure non-equilibrium plasmajet technology: Atmospheric pressure non-equilibrium plasma jet technology: Generalfeatures, specificities and applications in surface processing of materials. Surf. Coat. Technol. 2017, 322, 174-201. [CrossRef]

28. Palumbo, F.; Camporeale, G.; Yang, Y.-W.; Wu, J.-S.; Sardella, E.; Dilecce, G.; Calvano, C.D.; Quintieri, L.; Caputo, L.; Baruzzi, F.; et al. Direct plasma deposition of lysozyme-embedded bio-composite thin films. Plasma Process. Polym. 2015, 12, 1302. [CrossRef]

29. Cheng, Y.C.; Hsiao, C.P.; Liu, Y.H.; Yang, C.H.; Chiang, C.Y.; Lin, T.R.; Yang, Y.W.; Wu, J.S. Enhancing adhesion and polymerization of lipase-plasma-polymerized-ethylene coatings deposited with planar dielectric-barrier-discharge-type aerosol-assisted atmospheric-pressure plasma system. Plasma Process. Polym. 2018, 15, 1700173. [CrossRef]

30. Mauchauffé, R.; Bonot, S.; Moreno-Couranjou, M.; Detrembleur, C.; Boscher, N.D.; Van De Weerdt, C.; Duwez, A.-S.; Choquet, P. Fast atmospheric plasma deposition of bio-inspired catechol/quinone-rich nanolayers to immobilize NDM-1 enzymes for water treatment. Adv. Mater. Interfaces 2016, 3, 1500520. [CrossRef]

31. Afshari, E.; Mazinani, S.; Ranaei-Siadat, S.-O.; Ghomi, H. Surface modification of polyvinyl alcohol/malonic acid nanofibers by gaseous dielectric barrier discharge plasma for glucose oxidase immobilization. Appl. Surf. Sci. 2016, 385, 349-355. [CrossRef]

32. Morshed, M.N.; Behary, N.; Bouazizi, N.; Guan, J.; Chen, G.; Nierstrasz, V. Surface modification of polyester fabric using plasma-dendrimer for robust immobilization of glucose oxidase enzyme. Sci. Rep. 2019, 9, 15730. [CrossRef] [PubMed]

33. Malinowski, S.; Herbert, P.A.F.; Rogalski, J.; Jaroszynska-Wolinska, J. Laccase enzyme polymerization by soft plasma jet for durable bioactive coatings. Polymers 2018, 10, 532. [CrossRef] [PubMed]

34. Malinowski, S.; Wardak, C.; Jaroszynska-Wolinska, J.; Herbert, P.A.F.; Panek, R. Cold plasma as an innovative construction method of voltammetric biosensor based on laccase. Sensors 2018, 18, 4086. [CrossRef] [PubMed]

35. Fanelli, F.; Fracassi, F.; Lapenna, A.; Angarano, V.; Palazzo, G.; Mallardi, A. Atmospheric pressure cold plasma: A friendly environment for dry enzymes. Adv. Mater. Interfaces 2018, 24, 1801373. [CrossRef]

36. Bahnev, B.; Bowden, M.D.; Stypczyńska, A.; Ptasińska, S.; Mason, N.J.; Braithwaite, N.S.J. A novel method for the detection of plasma jet boundaries by exploring DNA damage. Eur. Phys. J. D 2014, 68, 140. [CrossRef]

37. Arjunan, K.P.; Sharma, V.K.; Ptasinska, S. Effects of atmospheric pressure plasmas on isolated and cellular DNA-A review. Int. J. Mol. Sci. 2015, 16, 2971-3016. [CrossRef]

38. Adhikari, E.R.; Samara, V.; Ptasinska, S. Influence of $\mathrm{O}_{2}$ or $\mathrm{H}_{2} \mathrm{O}$ in a plasma jet and its environment on plasma electrical and biochemical performances. J. Phys. D 2018, 51, 185202. [CrossRef]

39. Adhikari, E.R.; Ptasinska, S. Correlation between helium atmospheric pressure plasma jet (APPJ) variables and plasma induced DNA damage. Eur. Phys. J. D 2016, 70, 180. [CrossRef] 
40. Kousal, J.; Shelemin, A.; Kylián, O.; Slavínská, D.; Biederman, H. In-situ monitoring of etching of bovine serum albumin using low-temperature atmospheric plasma jet. Appl. Surf. Sci. 2017, 392, 1049-1054. [CrossRef]

41. Joslin, J.M.; McCall, J.R.; Bzdek, J.P.; Johnson, D.C.; Hybertson, B.M. Aqueous plasma pharmacy: Preparation methods, chemistry, and therapeutic applications. Plasma Med. 2016, 6, 135-177. [CrossRef] [PubMed]

42. Da Ponte, G.; Sardella, E.; Fanelli, F.; Paulussen, S.; Favia, P. Atmospheric pressure plasma deposition of poly lactic acid-like coatings with embedded elastin. Plasma Process. Polym. 2014, 4, 345-352. [CrossRef]

43. Lackmann, J.-W.; Baldus, S.; Steinborn, E.; Edengeiser, E.; Kogelheide, F.; Langklotz, S.; Schneider, S.; Leichert, L.I.O.; Benedikt, J.; Awakowicz, P.; et al. A dielectric barrier discharge terminally inactivates RNase A by oxidizing sulfur-containing amino acids and breaking structural disulfide bonds. J. Phys. D 2015, 48, 494003. [CrossRef]

44. Misra, N.N.; Pankaj, S.K.; Segat, A.; Ishikawa, K. Cold plasma interactions with enzymes in foods and model systems. Trends Food Sci. Technol. 2016, 55, 39-47. [CrossRef]

45. Rezaei, F.; Vanraes, P.; Nikiforov, A.; Morent, R.; De Geyter, N. Applications of plasma-liquid systems: A review. Materials 2019, 12, 2751. [CrossRef] [PubMed]

46. García-Borrón, J.C.; Solano, F. Molecular anatomy of tyrosinase and its related proteins: Beyond the histidine-bound metal catalytic center. Pigment Cell Res. 2002, 15, 162-173. [CrossRef]

47. Halaouli, S.; Asther, M.; Sigoillot, J.C.; Hamdi, M.; Lomascolo, A. Fungal tyrosinases: New prospects in molecular characteristics, bioengineering and biotechnological applications. J. Appl. Microbiol. 2006, 100, 219-232. [CrossRef]

48. Selinheimo, E.; NiEidhin, D.; Steffensen, C.; Nielsen, J.; Lomascolo, A.; Halaouli, S.; Record, E.; O’Beirne, D.; Buchert, J.; Kruus, K.J. Comparison of the characteristics of fungal and plant tyrosinases. J. Biotechnol. 2007, 130, 471-480. [CrossRef]

49. Wong, C.M.; Wong, K.H.; Chen, X.D. Glucose oxidase: Natural occurrence, function, properties and industrial applications. Appl. Microbiol. Biotechnol. 2008, 78, 927-938. [CrossRef]

50. Fanelli, F.; Fracassi, F.; d'Agostino, R. Deposition of hydrocarbon films by means of helium-ethylene fed glow dielectric barrier discharges. Plasma Process. Polym. 2005, 2, 688-694. [CrossRef]

51. Bosso, P.; Fanelli, F.; Fracassi, F. Deposition of water-stable coatings containing carboxylic acid groups by atmospheric pressure cold plasma jet. Plasma Process. Polym. 2016, 13, 217-226. [CrossRef]

52. Massines, F.; Sarra-Bournet, C.; Fanelli, F.; Naudé, N.; Gherardi, N. Atmospheric pressure low temperature direct plasma technology: Status and challenges for thin film deposition. Plasma Process. Polym. 2012, 9 , 1041-1073. [CrossRef]

53. Brandenburg, R. Dielectric barrier discharges: Progress on plasma sources and on the understanding of regimes and single filaments. Plasma Sources Sci. Technol. 2017, 26, 053001. [CrossRef]

54. Fanelli, F.; d'Agostino, R.; Fracassi, F. Effect of gas impurities on the operation of dielectric barrier discharges fed with $\mathrm{He}, \mathrm{Ar}$, and Ar- $\mathrm{C}_{3} \mathrm{~F}_{6}$. Plasma Process. Polym. 2012, 9, 1041-1073. [CrossRef]

55. Rich, S.A.; Dufour, T.; Leroy, P.; Reniers, F.; Nittler, L.; Pireaux, J.J. LDPE surface modifications induced by atmospheric plasma torches with linear and showerhead configurations. Plasma Process. Polym. 2015, 12, 771-785. [CrossRef]

56. Van Vrekhem, S.; Vloebergh, K.; Asadian, M.; Vercruysse, C.; Declercq, H.; Van Tongel, A.; De Wilde, L.; De Geyter, N.; Morent, R. Improving the surface properties of an UHMWPE shoulder implant with an atmospheric pressure plasma jet. Sci. Rep. 2018, 8, 4720. [CrossRef]

57. Ionita, E.R.; Ionita, M.D.; Stancu, E.C.; Teodorescu, M.; Dinescu, G. Small size plasma tools for material processing at atmospheric pressure. Appl. Surf. Sci. 2009, 255, 5448-5452. [CrossRef]

58. Chandrashekaraiah, T.H.; Bogdanowicz, R.; Rühl, E.; Danilov, V.; Meichsner, J.; Thierbach, S.; Hippler, R. Spectroscopic study of plasma polymerized a-C:H films deposited by a dielectric barrier discharge. Materials 2016, 9, 594. [CrossRef] [PubMed]

59. Fischer, H.; Polikarpov, I.; Craievich, A.F. Average protein density is a molecular-weight-dependent function. Protein Sci. 2004, 13, 1041-1073. [CrossRef] [PubMed] 
60. Fumagalli, F.; Hanus, J.; Kylian, O.; Rossi, F. In situ quartz crystal microbalance measurements of thin protein film plasma removal. Plasma Process. Polym. 2012, 9, 188-196. [CrossRef]

61. Desimoni, E.; Brunetti, B. X-ray photoelectron spectroscopic characterization of chemically modified electrodes used as chemical sensors and biosensors: A review. Sensors 2015, 3, 70-117. [CrossRef]

(C) 2020 by the authors. Licensee MDPI, Basel, Switzerland. This article is an open access article distributed under the terms and conditions of the Creative Commons Attribution (CC BY) license (http://creativecommons.org/licenses/by/4.0/). 